\title{
Governance of Migrant Worker Recruitment: A Rights-Based Framework for Countries of Origin
}

\author{
Bassina FARBENBLUM* \\ Faculty of Law, UNSW Australia \\ b.farbenblum@unsw.edu.au
}

\begin{abstract}
A vast private recruitment industry has emerged across South and Southeast Asia, driven by exponential increases in migrant workers seeking temporary low-wage jobs abroad. Many workers encounter mistreatment which is traceable to systemic recruiter misconduct. Could origin countries better protect their citizens and render recruiters more accountable? This paper presents a novel, rights-based recruitment governance framework to tackle this challenge, based on empirical studies conducted across Asia. Section I examines recent regulatory efforts and illustrates their limited effectiveness absent such a guiding framework. Section II elucidates and applies the key elements of the framework, including: incorporation of human rights standards; enforceable legal rights and obligations; effective implementing institutions and processes; and empowered participation of migrant workers in key labour migration processes and decisions. Section III identifies structural and practical obstacles to regulatory enforcement that the framework addresses, creating necessary conditions for transnational market-based reforms and responsible recruitment within origin countries. Section IV concludes that the framework provides countries of origin with a feasible path to better protecting migrant workers within a sustainable development strategy.
\end{abstract}

Over the past two decades, there has been an exponential increase in the number of individuals leaving their homes for temporary work in low-wage sectors abroad. Along with this expansion has come a mounting focus on the mistreatment of low-wage migrant workers in their countries of employment, and on the need for greater employer accountability. In recent times, particular attention has been focused on low-wage migrants in the Middle East, most

\footnotetext{
Solicitor (New South Wales) and Attorney (State of New York and US Court of Appeals for the Third Circuit). Senior Lecturer, UNSW Law. Director, Migrant and Refugee Rights Project, Australian Human Rights Centre, UNSW Law. The author is thankful for the insightful comments that Judy Fudge, Jennifer Gordon, and Andrew Kuper provided on earlier drafts, and for research assistance capably provided by Alisha Mathew. The author is also grateful to the Open Society Foundations International Migration Initiative (OSF IMI) for providing the Fellowship during which this paper was written, and for their generous support for the Migrant Worker Access to Justice Project (MWAJP) that gave rise to the rich empirical data underpinning aspects of the paper. Finally, the author is deeply appreciative of the many thoughtful discussions that she has had over the past few years with MWAJP co-researchers Sarah Paoletti, Eleanor Taylor-Nicholson, Bandita Sijapati, and Dina Nuriyati, as well as with Elizabeth Frantz and Maria Teresa Rojas at OSF IMI, and policy-makers, migrant workers, and their advocates too numerous to mention individually, that stimulated the thinking behind many elements of this paper.
} 
of whom originate from South and Southeast Asia. ${ }^{\mathrm{I}}$ The harms that many of these millions of men and women encounter during their employment abroad are now well known. ${ }^{2}$

What is less well recognized is that although the employment relationship lies at the heart of labour migration, it sits within a broader transnational web of relationships, spanning countries of origin, transit, and destination, which contributes to the mistreatment of migrant workers. Scholars have only recently begun to consider the rampant, systemic abuses that migrant workers encounter during recruitment in their countries of origin. These abuses invariably form the first chapter-or in some cases, the entire book-of the migrant worker exploitation story, particularly in South and Southeast Asia. In these regions, private recruitment agencies ${ }^{3}$ and sub-agents have become particularly integral to international migration, and have increased exponentially in number over the past three decades. ${ }^{4}$ It is also in these regions that abusive recruitment practices have become "endemic-the norm". 5

As more information emerges on the impact of recruitment practices on migrant worker mistreatment globally, an obvious next question is whether a different approach to governance of recruitment could enable migrant workers' home countries to play a more effective role in preventing the abuse of their citizens. This paper provides a preliminary answer to that question. It contends that (I) the absence of a rights-based and migrantcentred approach to the governance of recruitment in countries of origin partially explains the limited effectiveness of some recent legislative and policy efforts to curb abusive practices; and that (2) the adoption of such an approach would improve migrant worker protection and private sector accountability throughout the entire migration process.

Little has been written on what a rights-based approach to labour migration governance would mean for migrants' home countries in practice, despite increasing recognition of its importance. ${ }^{6}$ Therefore, this paper proposes a set of defining principles for a rights-based

I. See e.g. Amnesty International, “The Dark Side of Migration: Spotlight on Qatar's Construction Sector Ahead of the World Cup" (October 2013), online: Amnesty International <https://www.amnestyusa.org/ sites/default/files/mde22orozor zeng.pdf>; Hélène HARROFF-TAVEL and Alix NASRI, "Tricked and Trapped-Human Trafficking in the Middle East" International Labour Organization (April 20I3), online: ILO <http://www.ilo.org/wcmsp5/groups/public/_arabstates/—ro-beirut/ documents/publication/wcms_2II2I4.pdf>; and "Walls at Every Turn: Abuse of Migrant Domestic Workers through Kuwait's Sponsorship System” Human Rights Watch (October 2010), online: Human Rights Watch < http://www.hrw.org/sites/default/files/reports/kuwaitıoıowebwcover. pdf $>$ at 103 .

2. They include, for example, partial payment or non-payment of agreed wages, dangerous work conditions, inadequate rest, inhumane housing conditions, fundamental changes in the agreed nature or conditions of work (sometimes through a "substituted" contract on arrival), the employers' or recruitment agencies' confiscation of workers' identity and travel documents, and in some cases, confinement to the workplace and/or physical or sexual abuse. Ibid. For abuses commonly suffered by domestic workers, see United Nations Committee on Migrant Workers, General Comment No.I on Migrant Domestic Workers, UN Doc. CMW/C/GC/I (20I I) at para. I3.

3. Convention Concerning Private Employment Agencies, I9 June I997, ILO No. I 8 (entered into force Io May 200o), online: International Labour Organization [ILO] <http://www.ilo.org/dyn/normlex/en/f? p=NORMLEXPUB:I 2 I00:0::NO::PI2100_INSTRUMENT_ID:3 $12326>$ [ILO Private Employment Agencies Convention], art. I(I) (defining "private employment agency").

4. International Organization for Migration, "Recruitment Monitoring and Migrant Welfare Assistance: What Works?" (2OI 5), online: IOM <http://apmigration.ilo.org/resources/recruitment-monitoring-andmigrant-welfare-assistance-what-works $>$ at I 7 and 48-9 (tabulating approximate number of licensed recruitment agencies in select Asian countries of origin in 2014) [IOM].

5. Ibid., at I.

6. See e.g. Open Working Group on Labour Migration and Recruitment, "Civil Society Contributions to the Special Rapporteur's Report to the UN Human Rights Council on Migrant Labour 
recruitment governance framework, ${ }^{7}$ which may assist states and other stakeholders to translate a commitment to rights-based governance into effective regulatory reform. ${ }^{8}$

The rights-based recruitment governance framework proposed in this paper has four key elements. The first is the entrenchment of rights-holders and duty-bearers in law. This includes the establishment of enforceable legal rights on the part of migrant workers and of corresponding obligations on the part of states and relevant private actors. The second element is the enforcement of rights and responsibilities in practice, which includes ensuring the accountability of relevant duty-bearers and access to remedies on the part of migrant workers. This requires the development of transparent and effective implementing institutions and processes. The third element is the informed and empowered participation of migrant workers in key labour migration processes and decisions. This is both at the individual level (including workers' empowered pre-departure decision-making) and at the systemic level (including migrants' empowered participation in labour migration policy development and recruitment agency licensing decisions). Participation is both an end in itself and a means for ensuring that the recruitment governance framework responds to migrant workers' lived recruitment experiences, multiple vulnerabilities, and development goals. The fourth element is the incorporation of a range of international human rights and labour rights obligations and standards that apply to migrant worker recruitment, to many of which countries of origin in Asia have already committed themselves.

Section I of the paper sets out some common systemic recruitment practices in countries of origin throughout Asia and elsewhere which either render migrant workers vulnerable to mistreatment abroad or are inherently abusive. Section II illustrates the limited abuse prevention and accountability achieved by recent regulatory efforts

Recruitment" (20I4), online: OWGLMR <http://recruitmentreform.org/wp-content/uploads/20I4/I I/OWGReport-to-the-SR-FINAL.pdf> [OWGLMR]; ILO, "International Labour Migration: A Rights-Based Approach" (20I0), online: ILO <http://www.upf.edu/gritim/_pdf/rights_based_approach.pdf >; and UN Office of the High Commission for Human Rights, "Migration and Human Rights: Improving Human RightsBased Governance of International Migration” (2013), online: UNOHCHR: <http://www.ohchr.org/ Documents/Issues/Migration/MigrationHR_improvingHR_Report.pdf> [UNOHCHR]. See also Juanita ELIAS, "Struggles over the Rights of Foreign Domestic Workers in Malaysia: The Possibilities and Limitations of 'Rights Talk'" (2008) 37 Economy and Society 282 at 282 (observing that a rights-based approach to migration has come to underpin the work of the ILO and advocacy groups, in contrast to other prevailing understandings of migration based around security/immigration control and economic efficiency).

7. The principles of a rights-based approach and their sources are more fully addressed in Section III.A of this paper.

8. As there is no standard definition of a rights-based approach to governance, the principles of the rights-based governance framework proposed here have been drawn from general principles articulated in a number of sources, including key documents outlining a rights-based approach to development, and adapted by the author to the migrant recruitment context. See also United Nations Development Group, "The Human Rights Based Approach to Development Cooperation: Towards a Common Understanding Among UN Agencies" (2003), online: UNDG <http:/hrbaportal.org/the-human-rights-based-approach-to-development-cooperation-towards-a-common-understanding-among-un-agencies> [UNDG]; Bacre NDIAYE, "Addressing Irregular Migration Through a Human Rights Based Approach" (I December 20II), online: UNOHCHR <http://www.ohchr.org/Documents/Issues/MHR/StatementBN_HRBA_Irregular_Migration.pdf> (Address by Bacre Ndiaye, Director, Human Rights Council and Special Procedures Division before the Global Forum on Migration and Development); and Scottish Human Rights Commission, "Human Rights Based Approach", online: SHRC <http://www.scottishhumanrights.com/humanrights/humanrightsbasedapproach> (last accessed I8 June 20I5) [SHRC]. For discussion of the legitimacy of, and support for, a rights-based approach to labour migration governance in Asia, see Elias, supra note 6, and references cited infra note 28 . 
that are not situated within a rights-based recruitment governance framework and are not grounded in migrant workers' recruitment experiences. This includes inadequacies of public laws and regulations governing recruitment, as well as private contracts governing workers' relationships with recruitment agencies. Section III contends that the limited effectiveness of these instruments is not inevitable. It sets out the core elements of a rights-based recruitment governance framework that would address a number of the challenges identified in the preceding section. After discussing the elements of the framework and their application, the section anticipates critiques of the framework in light of non-enforcement of existing protective laws in countries of origin. To address these critiques, it identifies a number of key structural and practical obstacles to enforcement that the framework would in fact address. It concedes that there are geopolitical and market-based structural forces that currently drive non-compliance and impede enforcement of protective laws, and that these require transnational reforms to transform migrant worker recruitment and employment business models in partnership with destination countries. However, it also illustrates that a rights-based governance approach within countries of origin is essential to that transformation, and can independently address a number of practical obstacles to recruiter accountability and migrant worker protection within countries of origin.

The paper relies on empirical studies conducted by the author and her colleagues for new in-depth analyses of the situations of migrants going from South and Southeast Asia to the Middle East along the fastest-growing migration corridor globally-a corridor in which the particular challenges to rights enforcement in destination countries $^{9}$ amplify the need for improved protection of migrant workers by their home countries. In particular, examples and evidence from the Indonesian and Nepalese contexts, arising from the first comprehensive studies of accountability in recruitment and migrant workers' access to justice in countries of origin, conducted by the author and colleagues between $20 \mathrm{I} 2$ and $20 \mathrm{I} 4{ }^{\mathrm{IO}}$ will be considered. Case-studies conducted in both countries, one in South and one in Southeast Asia, are revealing because each country has made especially significant efforts over the past decade to better regulate recruitment and placement of workers overseas, and has developed processes and programmes intended to enable migrant workers to access remedies at home and through their consulates. ${ }^{\text {II }}$ Nevertheless, in both countries, as well as other countries of origin around the region, systemic misconduct within recruitment persists, recruiter

9. See e.g. Alix NASRI and Wissam TANNOUS, "Access to Justice for Migrant Workers in Lebanon" International Labour Organization (20I4), online: ILO <http://www.ilo.org/wcmsp5/groups/public/ @arabstates/@ro-beirut/documents/genericdocument/wcms_247033.pdf $>$. The kafala system in the Gulf States strongly discourages migrant workers from bringing claims against employers because workers' visa status is tied to a single employer and they are liable to deportation if they leave the employer. See also Human Rights Watch, supra note I at $4-6$.

Io. Bassina FARBENBLUM, Eleanor TAYLOR-NICHOLSON, and Sarah PAOLETTI, "Migrant Workers' Access to Justice at Home: Indonesia" Migrant Worker Access to Justice Project (20I3), online: MWAJP $<$ http://www.migrantworkerjustice.org/sites/default/files/2013 Io/Migrant \% 20Workers \% 20Access \% 20to \% 20Justice\% 20at \% 20Home-Indonesia-IO-O3-20I3\%20\% 28US\%29_I.pdf> [MWAJP]; and Sarah PAOLETTI, Eleanor TAYLOR-NICHOLSON, Bandita SIJAPATI, and Bassina FARBENBLUM, "Migrant Workers' Access to Justice at Home: Nepal” MWAJP (20I4), online: MWAJP <http://www.migrantworkerjustice.org/sites/default/files/migrant-nepal-report-english-20I406IO_I_o.pdf >.

II. Ibid. 
accountability remains elusive, and migrant worker protection and access to remedies remain limited.

This paper lays out the contours of a practical rights-based governance approach for recruitment that could bring countries of origin in Asia and elsewhere far closer to achieving their stated protection and accountability goals.

\section{RECRUITMENT PRACTICES IN COUNTRIES OF ORIGIN}

Governance of migrant worker recruitment is exceptionally complex because it demands oversight over hundreds or often thousands of private actors, operating formally and informally across national and international borders. This includes private recruitment agencies (PRAs), sometimes called manpower agencies or private employment agencies, located within the capital or major cities in countries of origin. It also includes large numbers of individual sub-agents, also called intermediaries or brokers, who recruit workers at the village level. Across Asia, where privatized recruitment is most common, ${ }^{\mathrm{I} 2}$ this constellation of private actors forms a fragmented industry that has witnessed exponential growth over the past two decades, as their services have become indispensable, and indeed mandated, in many countries of origin.

Recruitment agencies and sub-agents serve an important function by enabling millions of aspiring low-wage workers to access otherwise inaccessible employment opportunities abroad. In particular, they provide aspiring workers with information about foreign employment, and assistance in obtaining necessary documentation and navigating complex government requirements for working abroad.

At the same time, systemic misconduct within the recruitment industry often creates the conditions for, or directly causes, many of the abuses that migrant workers suffer. ${ }^{\mathrm{I}}{ }^{3}$ For example, recruitment agencies and individual sub-agents routinely command high fees and charges from migrant workers, ${ }^{\mathrm{I}}$ commonly justifying them by misrepresenting the salary or conditions of work which the prospective migrant can expect. ${ }^{15}$ Based on the salary they anticipate receiving, migrant workers often sell

I2. See IOM, supra note 4 .

I3. See generally Paoletti et al., supra note ıо, and Farbenblum et al., supra note ıо.

I4. Under art. 7 of ILO Private Employment Agencies Convention, supra note 3, recruitment agencies may not charge workers any fees or costs, unless the state makes an exception that is "in the interest of the workers concerned". The more recent ILO Forced Labour (Supplementary Measures) Recommendation 20I4, i I June 20I4, ILO No. 203, online: ILO <https:/www.ilo.org/dyn/normlex/en/f?p=NORMLEXPUB:I2 IO०:०:: NO:I2 IOO:PI2 IOO_INSTRUMENT_ID:3 I 74688:NO> [20I4 ILO Forced Labour Recommendation], arts. 4 (i) and $8(\mathrm{a})$, recommends that states entirely eliminate the charging of recruitment fees to migrant workers. Similarly, the ILO Multilateral Framework on Labour Migration: Non-binding Principles and Guidelines for a Rights-based Approach to Labour Migration (2006), online: ILO <http://www.ilo.org/wcmsp5/groups/ public/—asia/—ro-bangkok/documents/publication/wcms_I46243.pdf $>$ at 25, states that governments should ensure that migrant workers are not directly or indirectly charged recruitment fees. It is now the position of many policy institutions and human rights groups that recruitment fees should always be borne by employers, and that the charging of any fees to migrant workers should be prohibited. Nevertheless, most states continue to allow agencies to charge fees up to a specified limit, which in practice is commonly exceeded.

I 5. Ray JUREIDINI, "Migrant Labour Recruitment to Qatar: Report for Qatar Foundation Migrant Worker Welfare Initiative" Bloomsbury/ Qatar Foundation Journals (20I4), online: Qatar Foundation <http://www.qscience.com/userimages/ContentEditor/I4048I I 243939/Migrant_ Labour_Recruitment_to_Qatar_Web_Final.pdf $>$ at 137 . 
personal property and take out loans from local moneylenders to cover these inflated recruitment fees and costs. ${ }^{16}$ Such loans commonly attract high or indeed usurious interest rates, ${ }^{17}$ resulting in many workers departing from their country of origin with high mounting debts. These debts compel workers to remain in exploitative employment situations abroad in order to pay off their loans, in circumstances that may give rise to forced labour. ${ }^{\mathrm{I} 8}$ Workers also acquiesce to poorer work conditions or lower wages than those promised by the sub-agent or recruitment agency at home in fear of deportation, as well as the double threat of debt-laden unemployment, if they complain. ${ }^{\text {I9 }}$

In addition to fee and debt issues, migrant workers are also made more vulnerable to abuse abroad by recruitment agencies' failure to provide them with required training and information ${ }^{20}$; for example, copies of key documents such as their recruitment and/or employment contract and insurance policy. Outright fraud is not uncommon, especially at the village level, with prospective workers commonly recruited (and paying fees) for positions that do not exist, or being sent abroad with falsified documentation. Finally, when these workers encounter harms, recruitment agencies commonly fail either to provide them with the compensation to which they are entitled, or to adequately account for their misconduct. ${ }^{2 \text { I }}$ These practices are remarkably similar across South and Southeast Asia, ${ }^{22}$ and indeed globally. ${ }^{23}$

I6. Ibid., at 6.

I7. For example, in Nepal migrants pay anywhere from fifteen to sixty percent in interest to moneylenders, as compared to the official bank rates of between eight and fourteen percent. Amnesty International, "False Promises: Exploitation and Forced Labour of Nepalese Migrant Workers” (December 20I I), online: Amnesty International <https://www.amnesty.org/en/documents/ASA3 I/oo7/20I I/en/> at 34 .

I 8. See e.g. Julia O’CONNELL DAVIDSON, “Troubling Freedom: Migration, Debt and Modern Slavery” (2013) I Migration Studies I76. The ILO estimates that there are 600,000 forced labour victims in the Middle East; Harroff-Tavel and Nasri, supra note I. There is considerable debate regarding the point at which routine abuses in recruitment constitute forced labour or human trafficking, in the light of international definitions contained in art. 2 of the Convention Concerning Forced or Compulsory Labour, 28 June I930, ILO No. C29 (entered into force I May I932), online: ILO <http://www.ilo.org/dyn/normlex/ en/f?p=NORMLEXPUB:I 2 Iоo:०::NO::PI 2 Ioo_ILO_CODE:Co29> and Protocol to Prevent, Suppress and Punish Trafficking in Persons, Especially Women and Children, Supplementing the United Nations Convention against Transnational Organized Crime, I 5 November 2000, 2237 U.N.T.S. 3I9, UN Doc. $\mathrm{A} / 55 / 383$ (entered into force 25 December 2003) at art. 3 [Palermo Protocol]. For key perspectives in that debate, see Jennifer GORDON, "Global Labour Recruitment in a Supply Chain Context” ILO Fundamentals Working Papers (2OI 5), online: ILO < http://www.ilo.org/wcmsp 5/groups/ public/—dgreports/—dcomm/documents/publication/wcms_377805.pdf $>$ at I, note 5 .

I9. ILO, "A Global Alliance Against Forced Labour: Global Report Under the Follow Up to the ILO Declaration on the Fundamental Principles and Rights at Work" (2005), online: ILO <http://www.ilo. org/wcmsp5/groups/public/—ed_norm/_declaration/documents/publication/wcms_o8I882.pdf > at 2 and 5 .

20. See e.g. Human Rights Watch, supra note I at 23; Amnesty International, supra note I7 at 52-60; Farbenblum et al., supra note Io at 48-5I, 65-6; and Paoletti et al., supra note io at 65-8.

2I. See generally Farbenblum et al., supra note ıо; and Paoletti et al., supra note ıо.

22. Ibid.

23. See e.g. The International Labour Recruitment Working Group, "The American Dream Up for Sale: A Blueprint for Ending International Labour Recruitment Abuse" (20I3), online: ILRWG < https://fairlabourrecruitment.files.wordpress.com/20I3/oI/final-e-version-ilrwg-report.pdf $>$ at 6I [ILRWG]; and Jureidini, supra note I 5 . 


\title{
II. THE LIMITATIONS OF CURRENT RECRUITMENT GOVERNANCE MODELS
}

\author{
A. Statutory Governance of Recruitment: Licensing, \\ Hiring Processes, and Fees
}

Increasingly over the past two decades, countries of origin have recognized that unchecked misconduct within the recruitment industry at home contributes to migrant worker vulnerability and exploitation abroad. Many countries of origin now have laws, regulations, and policies governing private migrant worker recruitment agencies. For example, origin countries have established licensing schemes for recruitment agencies, imposed minimum requirements for individuals to be migrant workers, established procedures for the recruitment process and related rights and obligations of various parties, and established responsible institutions and/or systems for monitoring compliance with these laws. ${ }^{24}$ Most have established limitations on the fees which agencies may charge, ${ }^{25}$ and prescribed documentation that agencies must provide to the government in order to send a worker abroad, ${ }^{26}$ among other requirements. Foreign employment laws are the subject of ongoing law reform efforts in numerous countries. ${ }^{27}$

Despite these significant advances, many regulatory frameworks still focus primarily on developing procedural machinery for the efficient export of migrant workers, rather than on advancement and enforcement of migrant worker rights. ${ }^{28}$ As a result, current regulatory regimes still generally fail to protect workers and to hold recruitment

24. For a detailed analysis of the laws of a range of countries in South and Southeast Asia, see IOM, supra note 4; ILO, "Guide to Private Employment Agencies: Regulation, Monitoring and Enforcement" (2007), online: ILO <http://www.ilo.org/wcmsp5/groups/public/—ed_norm/—declaration/documents/instructionalmaterial/wcms_083275.pdf $>$ at 5-9; Dovelyn Rannveig AGUNIAS, "Running in Circles: Progress and Challenges in Regulating Recruitment of Filipino and Sri Lankan Labour Migrants to Jordan" Migration Policy Institute Reports (2000), online: Migration Policy Institute <http://www.migrationpolicy.org/research/regulating-recruitment-filipino-sri-lankan-migrants $>$ at 5-6.

25. The limitation versus abolition of recruitment fees remains a contentious issue. See supra note I 4 and accompanying text.

26. See e.g. Law 39/2004 on the Placement and Protection of Indonesian Migrant Workers Abroad (Id.) [hereinafter Law 39/2004], art. 5I.

27. For example, at the time of writing both Indonesia and Nepal are in the process of preparing bills for revised versions of each country's core foreign employment statute. In late 2013, Cambodia introduced eight new ministerial directives governing recruitment agencies, drafted in collaboration with the ILO: Regulations to Sub-Decree 190 on Sending Workers Abroad through Private Recruitment Agencies (2013) (Cam.).

28. A recent empirical study found that officials and parliamentarians in a range of South and Southeast Asian countries do not generally consider international human rights standards when devising labour migration laws and policies; IOM, supra note 4 at 4 . This is consistent with the view among a growing number of scholars that the "managed temporary labour migration" paradigm that undergirds the emerging global migration governance framework is one that places "great emphasis on the design of formal policies by which origin and destination states try to assert control over migratory flows and employment-that is, over income and profit generation as well as the securing of livelihoods through migration". However, the failure to focus on rights protection has meant that that "the majority of international migrants who labour in the bottom rungs of the global economy are not among the winners" within the "triple win" migration-development paradigm. Nicola PIPER, "Democratising Migration from the Bottom Up: The Rise of the Global Migrant Rights Movement" (2015) I 2 Globalizations 788 at $79 \mathrm{I}$, citing Xinying CHI, "Challenging Managed Temporary Labor Migration as a Model for Rights and Revelopment for Labor-sending Countries" (2008) 40 New York University Journal of International Law and Politics 497 at 500, and others. 
agencies accountable for misconduct. In particular, in the absence of an overarching rights-based and migrant-centred approach to governance, many laws suffer from vagueness of responsibilities as well as ineffective implementation and enforcement processes. These shortcomings and others are best illustrated by three areas of regulation that are now included in foreign employment laws in most countries of origin: (I) recruitment agency licensing laws; (2) laws which mandate recruitment agency conduct in relation to fees and information provided to workers about prospective jobs; and (3) laws which regulate individual sub-agents. ${ }^{29}$ Each area of regulation will be examined briefly below.

\section{Recruitment agency licensing laws}

Recruitment agency licensing schemes have improved markedly over recent years across both South and Southeast Asia. Nevertheless, many licensing frameworks still fail to fulfil their potential for improving recruiter accountability and migrant worker protection. This is due, in significant part, to the failure to locate licensing processes within a rights-based governance framework. Licensing schemes are generally directed towards establishing an industry of stable operators within government purview to replace the marketplace of agencies that operate in the shadows for a short period and disappear overnight when migrant workers raise claims against them-undoubtedly a fundamental advance towards recruiter accountability. For example, in Indonesia and Nepal, licensing schemes generally require recruitment agencies to establish their stability by demonstrating their financial solvency, facilities, and corporate governance, as well as by paying fees and a deposit. ${ }^{3 \circ}$ However, in neither country is an agency required to demonstrate that it has complied with worker protection obligations and remedied worker harms in response to complaints, in order to obtain or renew a licence to send migrant workers abroad. ${ }^{3 \mathrm{I}}$ The licensing process generally remains nontransparent, with no opportunity for migrant workers or civil society to contribute information or otherwise participate in licence-granting or renewal decisions. ${ }^{32}$ For example, migrant workers and their advocates are not informed when licence-granting or licence-renewing decisions are being made. There is no standardized procedural mechanism through which workers can inform decision-makers about an agency's previous misconduct or non-compliance with its protection obligations, or about previous associations between the agency's senior officials and other problematic recruitment agencies. Similarly, there is generally no automatic link between the recruitment licensing process and the complaints of mistreatment that migrant workers make to diplomatic missions abroad and to other government ministries. This further

29. For further information on how these areas are addressed within the laws of Afghanistan, Bangladesh, China, India, Indonesia, Nepal, Pakistan, Philippines, Sri Lanka, Thailand, and Viet Nam, see IOM, supra note 4 at 47-54 (regarding licensing), 49-5I (regarding sub-agents), and 54-6 (regarding fee regulation). See also $I L O$, supra note 24 for content of laws on each topic from a range of countries of origin.

30. See e.g. Nepal Foreign Employment Act 2064 (2007) (Np.), s. I I; and Indonesian Ministry of Manpower and Transmigration Regulation Io/2009 concerning Procedures for Granting, Extending and Withdrawing a License for Recruitment of Indonesian Migrant Workers, (7 May 2009)(Id.).

31. Ibid.

32. Ibid. 
deprives licensing regulators of the opportunity to use the licensing process to exclude exploitative agencies or individuals from recruiting migrant workers in the future.

Compounded with the failure to link licensing with migrant protection and to enable meaningful migrant worker participation in licensing decisions is the fact that countries of origin have not diligently enforced existing licensing requirements. As a result, recruitment in countries of origin continues to be performed largely by unlicensed agencies operating in the shadows, ${ }^{33}$ and by licensed agencies that routinely send migrant workers to jobs where salaries and conditions are different from those promised, and that fail to comply with their legal obligations to compensate workers for harms that occur. ${ }^{34}$ This is true even in countries like the Philippines, which has one of the most stringent recruitment licensing regimes-one of the few that is explicitly intended to ensure that recruitment agencies cannot send migrant workers to jobs where they would face abuse and exploitation. ${ }^{35}$ Although violation of those laws carries heavy penalties, many recruitment agencies continue to operate without a licence or to violate the conditions of their licence, because the law is not diligently enforced. The Task Force Against Illegal Recruitment, an interagency body responsible for the arrest and prosecution of illegal recruiters in the Philippines, reportedly had 20,000 unserved warrants for over two hundred large-scale illegal recruiters in $201 \mathrm{I} .^{36}$

\section{The hiring process, including information and fees}

In addition to strengthening licensing laws, countries of origin have also sought to protect migrant workers by regulating recruitment agency conduct during the hiring process. This includes enacting laws which regulate information provided to migrant workers, and laws which limit fees that may be charged. However, the effectiveness of these laws is similarly limited by the lack of a migrant-centred and rights-based governance approach. For example, to address the lack of accurate information being provided to workers prior to applying for a job, a number of countries of origin have established detailed processes for recruitment agencies' advertising of positions abroad and subsequent provision of information to migrant workers. ${ }^{37}$ However, these do not reflect the recruitment experience of many migrant workers, and are routinely circumvented through migrants' use of individual sub-agents at the local level. The vast majority of returned migrant workers who participated in the Nepal Access to Justice Study, to take only one example, received all information about their jobs through a

33. In Sri Lanka and the Philippines, despite relatively robust licensing laws, the estimated number of illegal recruitment agencies still far outnumbered the registered entities in 2006. Nilim BARUAH, "The Regulation of Recruitment Agencies: Experiences and Good Practices in Countries of Origin in Asia” in Christiane KUPTSCH, ed., Merchants of Labour (Geneva: International Institute for Labour Studies, 2006), 37 at 42 .

34. Farbenblum et al., supra note io.

35. See generally Julyn S. AMBITO and Melissa Suzette L. BANZON, "Review of Philippine Migration Laws and Regulations: Gains, Gaps, Prospects”, Philippine Institute for Development Studies, Discussion Paper Series No. 20II-37, June 20II at 37; and Philippine Overseas Employment Administration, "POEA Rules and Regulations Governing the Recruitment and Employment of Land-Based Overseas Workers" (2002), online: POEA <http://www.poea.gov.ph/rules/POEA Rules.pdf> [POEA].

36. Ambito and Banzon, supra note 35 at 13 .

37. See e.g. Law 39/2004 at art. 4 . 
local sub-agent or a contact in the destination country. Not a single participant reported going through the legislated process of applying for an advertised position, ${ }^{38}$ resulting in none of them benefiting from the legislated advertising requirements.

Implementation and enforcement problems similarly afflict states' efforts to address overcharging of recruitment fees beyond legislated limits. ${ }^{39}$ Recruitment costs have become an increasingly significant human rights and labour rights concern for numerous reasons. These include the inconsistency between the right to work and mandatory fee payment for access to a job and, at a practical level, the clear links between recruitment fees, migrant worker debt, and vulnerability to subsequent debt bondage and exploitation, as discussed earlier. ${ }^{40}$ Although many Asian countries of origin limit recruitment fees to one month's wages, workers are commonly charged three to four times this amount. ${ }^{4 \mathrm{I}}$ In the Philippines, for example, despite the introduction of regulations addressing recruitment fees in 2002 and 2006, instances of agencies overcharging workers beyond statutory fee limits have in fact increased over the past decade. ${ }^{42}$ Though foreign employment laws generally establish fines and sanctions for violations of these limits and other statutory obligations, they are imposed in few cases, and recruitment agencies commonly flout their statutory obligations with impunity. ${ }^{43}$ Moreover, fee limits are rarely accompanied by genuinely accessible procedural mechanisms through which migrant workers might recover improper fees and costs paid. For example, Nepal's foreign employment law establishes a right on the part of migrant workers to obtain a refund of overcharged fees. ${ }^{44}$ However, the procedural mechanism for bringing a claim against a recruitment agency is practically inaccessible to the majority of low-wage migrant workers. ${ }^{45}$ This inaccessibility is due to a host of barriers, including: (I) the mechanism's location in the capital far away from workers' homes; (2) migrants' very low awareness and understanding of their legal rights or processes for enforcing them; (3) unavailability of legal assistance; (4) fear of retaliation by the recruitment agency or individual agent; and (5) substantial backlogs and other structural problems in the operation of the procedural mechanism which undermine the availability of timely remedies. ${ }^{46}$

The same is true of many other statutory rights and obligations concerning the hiring process that similarly lack accessible enforcement mechanisms. In Indonesia, for example, the labour migration statute provides workers with some limited but important rights, such as rights to information, to equality of treatment, to the standard wage in the destination country, to a copy of the work contract, and to "receive a guarantee of protection of the law ... [for] violation of one's rights set out in

38. Paoletti et al., supra note io at 60.

39. See supra note $\mathrm{I}_{4}$ regarding the tension between abolition and limitation of recruitment fees.

40. See supra notes I4-I9 and accompanying text.

4I. Jureidini, supra note I 5 at 32-44.

42. Rex VERONA, "Licence to Exploit: a Report on the Recruitment Practices and Problems Experienced by Filipino Domestic Workers in Hong Kong" (I October 20I3), online: Alliance of Progressive Labour and Progressive Labour Union of Domestic Workers in Hong Kong <http://www.idwfed.org/en/resources/licenseto-exploit-a-report-on-recruitment-practices-and-problems-experienced-by-filipino-migrant-domestic-workersin-hong-kong/@@display-file/attachment_I > at x.

43. Paoletti et al., supra note ro at 96-8; and Farbenblum et al., supra note ro at I37.

44. Nepal Foreign Employment Act 2064 (2007) (Np.), s. 53.

45. Paoletti et al., supra note io at 80.

46. Ibid., at $\mathrm{I}_{42}-3$. 
the law for the duration of the placement abroad". ${ }^{47}$ Yet, these rights are unenforceable in practice, because the statute and regulations fail to establish consequences for non-fulfilment of government or recruitment agency obligations, and to establish mechanisms through which rights may be enforced. For example, the statute does not set out any method through which a worker may compel action by the government or a recruitment agency, or to obtain a remedy if he or she does not receive the required information or a copy of his or her contract. ${ }^{48}$

\section{Regulation of individual sub-agents at the village level}

As reflected in the discussion above, well-intentioned laws and policies governing migrant recruitment in countries of origin often fail to protect migrant workers in practice as, among other things, they do not reflect and respond to the actual recruitment experience and the vulnerabilities of low-wage migrant workers. A further key example of this problem is the singular, albeit important, regulatory focus on the conduct of recruitment agency corporations, leaving in the shadows the vast industry of individual sub-agents and other private actors down the recruitment chain who play a central role in the recruitment of migrant workers in reality.

This is a particularly significant problem in many South and Southeast Asian countries, where recruitment agencies are generally located either in the capital city or in other major cities, far from the villages and towns where most migrant workers live. ${ }^{49}$ Though some recruitment agencies have registered sub-agents or staff operating at the village level, it is far more common for a migrant's first point of contact to be an independent, individual sub-agent-generally someone known to the worker or introduced through friends, family, or a local figure of authority. ${ }^{\circ}{ }^{\circ}$ Most recruitment agencies use multiple independent sub-agents who identify workers and deliver them to the agency in the capital, often for a commission. ${ }^{51}$ In Indonesia, for example, a migrant worker's journey to the Middle East generally begins with a local sub-agent (known as a sponsor or calo) in her village. ${ }^{52}$ This local sub-agent ultimately connects the worker with a recruitment agency in Jakarta, ${ }^{53}$ entirely outside the country's system of regulated government oversight at both regional and local levels.

47. Law 39/2004, art. 8 .

48. In December 20I4, the Indonesian Ministry of Manpower enacted a new regulation governing recruitment that establishes a range of safeguards to better protect prospective migrant workers. See Manpower and Transmigration Regulation 22/20I4 (Id.). The regulation significantly strengthens the rights of migrant workers and the obligations of recruitment agencies. However, it does not establish mechanisms for compelling government or recruitment agencies' compliance with their obligations, or accessible mechanisms through which migrant workers may obtain remedies for breaches of their rights.

49. Farbenblum et al., supra note Io at I 24; Paoletti et al., supra note Io at I48; and Tasneem SIDDIQUI, "Protection of Bangladeshi Migrants Through Good Governance" in Kuptsch, supra note 33 at 63, 78.

50. Johan LINDQUIST, "Labour Recruitment, Circuits of Capital and Gendered Mobility: Reconceptualizing the Indonesian Migration Industry" (2010) 83 Pacific Affairs I I 5 at I I 5, I 25.

5I. In Nepal, for example, recruitment agencies have described working with between twenty and fifty individual agents at any one time. See Paoletti et al., supra note Io at 54, and Jureidini, supra note I 5 at 58 .

52. In some cases, friends and relatives may perform this function. For example, a survey of more than I, 500 Filipino domestic workers working in Hong Kong revealed that around one in eight used personal channels. Verona, supra note 42 at 24.

53. Lindquist, supra note 50 at $\mathrm{I} 25$. 
In Nepal, the worker generally only deals with the village sub-agent and has no contact whatsoever with the recruitment agency that ultimately sends him or her abroad. ${ }^{54}$ A 2013 study found that half of returned Nepali migrant workers did not even know whether their individual sub-agent worked for a recruitment agency-a clear impediment to seeking remedies from the agency at a later stage. ${ }^{55}$

Individual sub-agents commonly play a leading part in the migrant worker exploitation story. For example, in order to command higher fees from prospective migrant workers, sub-agents commonly misinform workers about the salary they will receive or the nature and key conditions of the work they will perform prior to going abroad $^{56}$ - the beginning of the cycle of migrant worker debt and exploitation. In a 20I3 study of Nepalese migrant workers returning from the Gulf, Amnesty International found that ninety-three percent reported that they had been deceived as to salary, nature of the job, hours of work, overtime pay, and/or rest days they could expect. ${ }^{57}$ Also, outright fraud and document falsification by sub-agents are not uncommon. ${ }^{58}$ Travelling on falsified documents often results in the migrant worker falling into an irregular immigration status in the destination country, rendering him or her liable to detention and deportation and making him or her far more vulnerable to exploitation and less able to access assistance.

Implementation of an effective framework for accountability of sub-agents appears to be a task so formidable and vexed that instead of acknowledging the key role that vast numbers of sub-agents play in migrant worker exploitation and the resources required to address the challenge, states have enacted relevant laws and acquiesced to systemic non-compliance.

Indonesia has addressed this problem by banning individual agents and by establishing a criminal offence which applies to any person who individually recruits Indonesian citizens for work abroad. ${ }^{59}$ Although migrant workers are usually recruited by a sub-agent, sub-agents are rarely if ever prosecuted. ${ }^{60}$ As would be expected, there is generally no formalized contractual relationship between (technically criminal) subagents and the recruitment agencies whom they work for, and there are no specific legal provisions or processes for holding the parties liable for each other's misconduct (though general legal principles of agency might be relevant and are yet to be tested). To the limited extent that workers might be able to pursue claims against sub-agents

54. The Asia Foundation, "Labour Migration Trends and Patterns: Bangladesh, India and Nepal" (2013), online: The Asia Foundation <http://asiafoundation.org/resources/pdfs/LabourMigrationTrendsandPatternsBangladeshIndiaandNepal20 I3.pdf $>$ at 18 .

55. Ibid.

56. Mohammad A. AUWAL, "Ending the Exploitation of Migrant Workers in the Gulf” (2010) 34 Fletcher Forum World Affairs 87 at 92. This intentional deception may, under certain conditions, give rise to human trafficking as defined in art. 3 of the Palermo Protocol, supra note I 8.

57. Amnesty International, supra note I7 at 6-7.

58. Farbenblum et al., supra note io at 46-7, and Paoletti et al., supra note io at I 50.

59. Law 39/2004, art. 4. The December 2014 Indonesian recruitment regulation requires that local-level recruitment be undertaken only by a verified employee of the recruitment agency in conjunction with government officials at the city/district level. Manpower and Transmigration Regulation 22/20I4 (Id.), art. I3. It is too early to know how this provision will be implemented and enforced, and whether it will have an impact on the widespread and entrenched use of independent brokers.

6o. Farbenblum et al., supra note io at 104-5. 
directly, communal relationships between workers and sub-agents commonly deter them from enforcing their rights or reporting fraud or other unlawful conduct to the authorities. ${ }^{6 \mathrm{I}}$ As a result, sub-agents generally operate with impunity, while recruitment agencies evade liability by distancing themselves from their sub-agents' misrepresentations and fees charged to workers, leaving workers with limited, if any, avenues for redress.

In contrast, Nepal has recognized the role that sub-agents play in the recruitment process, and requires recruitment agencies to register sub-agents whom they use. ${ }^{62}$ However, this ground-breaking law has had little impact, because agencies are not subject to any penalty for using unregistered sub-agents. As of June 20I3, only 290 of Nepal's estimated 80,000 sub-agents have been registered. ${ }^{63}$ In a further promising development, Nepal has established procedural mechanisms through which a migrant worker might hold an individual agent directly accountable for his or her misconduct. However, these mechanisms have similarly failed to achieve accountability or deter misconduct, as they remain practically inaccessible to most low-wage migrant workers throughout Nepal. ${ }^{64}$

The Indonesian and Nepali examples suggest that current efforts to govern individual agents are ineffective, at least in part, due to a failure to design and implement regulatory frameworks which reflect migrant workers' experiences and vulnerabilities and that have among their goals the need to ensure accountability, non-repetition of violations, and worker remedies for misconduct. It is possible that a version of Nepal's licensing model or an alternate model could prove far more effective in terms of migrant worker protection and recruiter accountability, if such a model employs the aforementioned and other elements of a rights-based approach set out in Section III below. ${ }^{65}$

As this and the two preceding sub-sections illustrate, the problems of statutory governance of migrant worker recruitment stem significantly from partial enforcement by authorities, but run far deeper: there is often a disconnect between regulatory content and migrants' recruitment experiences, a lack of detail on the scope of rights and obligations, and a lack of institutional responsibilities, resources, processes, and penalties to give content and force to the rights that have been established, including a lack of access and avenues for migrant worker participation in key governance processes and decisions. As is evident from the diverse country examples above, a number of key improvements in laws and regulations have yet to result in meaningful gains in migrant protection and recruiter accountability.

6I. Ibid. at 35, and Paoletti et al., supra note Io at I 55 .

62. Foreign Employment Act 2064 (2007) (Np.), s. 74.

63. Department of Foreign Employment, "Magh Monthly Progress Report Jan-Feb 20I4", cited in Paoletti et al., supra note Io at 55, and Bandita SIJAPTI and Amrita LIMBU, Governing Labour Migration in Nepal: An Analysis of Existing Policies and Institutional Mechanisms (Kathmandu: Himal Books, 20I 2) at 187 .

64. See generally Paoletti et al., supra note io; Eleanor TAYLOR-NICHOLSON, Sarah PAOLETTI, Bandita SIJAPATI, and Bassina FARBENBLUM, "Labour Migration Agents in Nepal: Regulation, Accountability and Alternatives", Centre for the Study of Labour and Mobility, Policy Brief, June 20I4, online: CESLAM <http://www.ceslam.org/index.php?pageName=publication\&pid=27> [CESLAM].

65. See infra Section III.A. 


\section{B. Contractual Governance of Recruitment Agencies}

In addition to the array of statutes, regulations, policies, directives, bilateral agreements, international conventions, and other public instruments that typically govern labour migration, many migrant labour relationships are also regulated by private contracts. These contracts generally govern migrant workers' relationships with recruitment agencies, employers, and insurers. Sometimes, they also govern relationships between commercial actors themselves, such as the recruitment agency in the country of origin, the placement agency in the destination country, and the employer. Many countries of origin and destination have sought to legislate minimum rights, responsibilities, and processes associated with labour migration contracts, and in some cases contracts are the subject of bilateral agreements between origin and destination countries. ${ }^{66}$ Although being far from perfect, many migrant worker recruitment, employment, and insurance contracts arguably provide migrant workers with stronger and clearer legal rights than can be found in many domestic laws and international instruments. Yet, across countries of origin, in the absence of a rightsbased, migrant-centred approach to the content, execution, and enforcement of those contracts, such contracts invariably fail to protect migrant workers and to facilitate accountability and redress when their terms are breached. In the context of contracts between migrant workers and recruitment agencies, this is largely attributable to unmitigated power and informational asymmetries between the parties in the pre-departure contract execution process, as well as a lack of genuinely accessible enforcement mechanisms after the contract is violated.

Indonesia provides a good example of these problems, despite its relatively robust statutory requirements for recruitment contracts. Indonesia's labour migration statute requires that a migrant worker enter into a "placement agreement" with an Indonesian recruitment agency prior to departure, separate from the employment agreement between the worker and the employer abroad. ${ }^{67}$ The statute sets out minimum requirements for the agreement that are reflected in a promising new standard placement agreement introduced in December $2014 .{ }^{68}$ The statute requires placement agreements to state that the recruitment agency is liable for compensating the worker if the employer does not fulfil the terms of the employer's contract with the worker. ${ }^{69}$ This means that if the worker is paid less, or if the conditions of the work are different from the terms of the employment contract that the worker signs pre-departure, the

66. See e.g. IOM, supra note 4 at 60 , describing and citing agreements that Saudi Arabia has concluded with Indonesia (20I4), Sri Lanka (20I4), and the Philippines (20I3).

67. Law 39/2004, arts. $5 \mathrm{I}(\mathrm{h}), 52$. In other countries, such as the Philippines, migrant workers enter into a single multiparty contract with origin and destination country recruiters as well as the employer. The contract establishes joint and several liability for contractual breaches among all of the respective parties. As origin countries look for "best practice" on contract design, further study is required to determine whether the single joint liability contract has any benefit in practice over parallel contracts.

68. Law 39/2004, art. 52(2). The standard agreement is set out in Annex I to Manpower and Transmigration Regulation 22/20I4 (Id.).

69. Law 39/2004, art. 52(2)(f). This requirement is reflected in art. IO.I of the standard placement agreement, which establishes that the migrant worker has a right to obtain compensation from the recruitment agency if the employer violates the employment agreement. Manpower and Transmigration Regulation 22/20I4 (Id.), Annex I, art. IO.I. 
recruitment agency is liable for compensating the worker for his or her loss-in effect, a joint liability provision. ${ }^{70}$

Despite this unusually forceful provision, Indonesian placement agreements have failed to protect workers in practice for several reasons. First, prior to the introduction of the 2OI 4 regulation, most placement agreements were prepared by the Indonesian recruitment agency in collaboration with the placement agency or employer abroad, ${ }^{7 \mathrm{I}}$ and did not necessarily contain the compensation guarantee as required..$^{22}$ Yet, despite their significance, these deficiencies in the content of the agreement have not been the main impediment to rights enforcement and accountability. Migrant workers confront overwhelming practical and structural obstacles to enforcing a placement agreement, and rarely, if ever, attempt to do so. Two separate studies have found that, despite statutory obligations to the contrary, Indonesian migrant workers frequently do not receive a copy of the placement agreement at all, and are unaware of its existence. ${ }^{73}$ Both studies found that workers were unaware of any rights they ought to have under the agreement, let alone possibilities for enforcement. ${ }^{74}$ For the few prospective workers who do receive the agreement, it generally fails to empower them to make informed decisions about the terms of their recruitment and employment abroad. This is because the agreement is usually provided only after the worker has already paid fees and is at the training centre far from home, and the contents of the agreement are generally not explained to the worker. ${ }^{75}$

Even for the few low-wage migrant workers who might be aware of their rights under the placement agreement, enforcement of the agreement in court would be onerous if not impossible due to systemic barriers such as the cost, time, expertise and evidence required, lack of legal assistance, and perceived or actual judicial bias and corruption. ${ }^{76}$

In late $20 \mathrm{I}_{3}$, the intergovernmental ASEAN Forum on Migrant Labour made a series of recommendations to Member States to "promote effective complaint mechanisms and grievance handling mechanisms" 77 in recognition of the inaccessibility of the courts to most

70. Explanatory notes to Law 39/2004, art. 52(2)(f). It is unclear how the recruitment agency's contractual liabilities interact with the employer's obligations under the parallel employment agreement, and with the worker's mandatory insurance coverage, which also covers losses related to wages and work conditions. See infra note 16I for reference to analysis of Indonesia's migrant worker insurance programme.

7I. Farbenblum et al., supra note io at 48 .

72. The Access to Justice study on migrant workers who go to the Middle East found that a sample placement agreement for Qatar lacked many of the statutorily required clauses, including the compensation guarantee. Ibid., at 64 .

73. Amnesty International, "Exploited for Profits, Failed by Governments: Indonesian Migrant Domestic Workers Trafficked to Hong Kong” (November 20I3), online: Amnesty International <https://www. amnesty.org/en/documents/ASAI $7 / \mathrm{O}_{4} \mathrm{I} / 20 \mathrm{I}_{3} / \mathrm{en} />$ at 35, and Farbenblum et al., supra note Io at 66.

74. Ibid.

75. Amnesty International, supra note 73 at 35 , and Farbenblum et al., supra note Io at 66. Art. 45 of Manpower and Transmigration Regulation 22/2OI4 (Id.) prohibits recruitment agencies from charging fees until the migrant worker has signed the placement agreement. Though an important protective measure, in the absence of effective oversight of brokers who charge fees before the worker gets to the recruitment agency, the future impact of this provision is unclear.

76. See Farbenblum et al., supra note ro at 99-106.

77. Recommendations endorsed by the 6th ASEAN Forum on Migrant Labour, 26-27 November 20I3, Brunei Darussalam (November 20I3), online: ILO < http://apmagnet.ilo.org/resources/recommendations-of-the-6th-asean-forum-on-migrant-labour>. 
Southeast Asian migrant workers. These included a recommendation that " $[\mathrm{d}]$ ispute resolutions, mediation, and other alternative dispute settlement mechanisms should be fully explored before administrative or judicial litigation processes". ${ }^{7}$ However, if based on existing models, the establishment of alternative dispute-settlement mechanisms is, in itself, unlikely to provide a solution to the problem of recruitment contract enforceability and rights protection. Though certainly more accessible than courts, existing dispute-resolution mechanisms are rarely rights-based and, as a result, are often themselves ineffective or inaccessible. In Indonesia, for example, there are substantial practical and structural barriers to accessing government-run programmes. Thus, very few workers who encounter problems attempt to recover compensation from recruitment agencies through the country's mediation programme. ${ }^{79}$ One of the most formidable barriers to access is geographical: mediation and other redress mechanisms are centralized in the capital city, far away from most workers' homes. This significantly increases the time, resources, and emotional costs of pursuing a remedy which is already prohibitive to many migrant workers. ${ }^{8 \circ}$ Migrant workers also receive limited information and assistance from embassies while they are abroad to obtain documentation to substantiate claims upon their return. ${ }^{8 \mathrm{I}}$ Moreover, the agency responsible for conducting mediations lacks the power to compel recruitment agencies' good faith participation in the process, or to compel compliance with an agreed settlement. As a result, recruitment agencies frequently do not appear at mediation sessions, and do not pay the agreed settlement amount in a timely manner. $^{82}$

Those who do make claims inevitably receive less than what they are owed. This is in part due to the lack of resourcing and professionalization of the mediation services, and in part due to the fact that migrant workers are not empowered to enforce their rights in any dispute with a recruitment agency. Few workers are able to access legal assistance or legal advice, and the limited pre-departure information they receive does not address the substantive and procedural information necessary for accessing remedies for contractual or other rights violations. ${ }^{83}$ As a result, the mediation process appears to be divorced from migrant workers' legal rights. Because the power asymmetry between workers and recruitment agencies remains largely uncorrected, workers simply accept-as is rational in this skewed context-a compromised outcome where compensation is far less than the amount to which they are entitled under the contract. ${ }^{84}$ As described by one migrant worker advocate, the experience of seeking remedies through alternative dispute resolution programmes is one where "in almost all cases the worker loses something". ${ }^{85}$

\footnotetext{
78. Ibid.

79. For a comprehensive description of the mediation and administrative dispute resolution mechanisms for migrant workers in Indonesia, see Farbenblum et al., supra note Io at chapter 6B (Administrative Dispute Resolution).

8o. Ibid., at $123-34$.

8I. Ibid.

82. Ibid., at 83 .

83. Ibid., at 127 .

84. Ibid., at $8 \mathrm{I}$.

85. Ibid., at 85 .
} 
The situation is similar in other Asian countries of origin. Even though migrant workers may have strong legal rights, enforcement mechanisms do not provide them with meaningful access to remedies. For example, under Nepal's Foreign Employment Act, a recruitment agency must, among other things, show the government a copy of the agreement between the worker and the agency in order to send a migrant worker abroad. ${ }^{86}$ Although Nepali law does not specify the required content of such contracts, this appears to have little impact because, in practice, recruitment agencies do not provide recruitment contracts to migrant workers at all. ${ }^{87} \mathrm{Nepal}$ also imposes statutory liability on recruitment agencies if the employment conditions differ from those promised in the employment contract provided to the worker before his or her departure. ${ }^{88} \mathrm{~A}$ recruitment agency is liable for compensating "the shortfall in remuneration and facilities", and can be prosecuted if the agency's staff intentionally misled the worker. ${ }^{89}$ Even in cases where an agency did not mislead the worker, if the employment conditions differ from those promised, the agency remains liable for compensating the worker's recruitment fees. ${ }^{90}$ However, similar to the case in Indonesia, the procedural mechanisms through which migrant workers may enforce their rights against recruitment agencies remain inaccessible to most migrant workers, and a significant portion of migrants who do seek remedies "settle" their cases, presumably walking away with far less than their legal entitlement..$^{\text {I }}$

The "amicable settlement" 92 problem afflicts even the Philippines, often hailed as the gold standard in recruitment governance because recruitment agencies may, under law, be held jointly and severally liable for employers' breaches of the employment contract. ${ }^{93}$ Although the Philippines has established institutions and dedicated mechanisms for the resolution of joint and several liability (JSL) compensation claims, the adjudicating bodies for such claims are inadequately funded and slow. ${ }^{94}$ Many migrant workers simply settle their claims at the outset for a fraction of what they are owed, and never progress to adjudication of the claim and enforcement of their legal rights, ${ }^{95}$ presumably because immediacy of payment is of paramount importance

86. Foreign Employment Act 2064 (2007) (Np.), s. I 5 (I)(h).

87. Paoletti et al., supra note to at 65 . Not a single migrant worker who participated in the Access to Justice study reported receiving a recruitment contract and experts were unaware of such contracts being provided.

88. Foreign Employment Act, 2064 (2007) (Np.), ss. 36, 55.

89. Foreign Employment Act, 2064 (2007) (Np.), s. 55; Paoletti et al., supra note Io at 8I.

90. Foreign Employment Act 2064 (2007) (Np.), s. 36.

9I. Farbenblum et al., supra note Io at I I7, I03-4. In the few cases in which a recruitment agency is ordered to compensate a migrant worker, the worker may still walk away empty-handed because recruitment agencies sometimes ignore the compensation order. Workers would then need to embark on a further round of court proceedings to enforce the order. See Paoletti et al., supra note Io at I 3 .

92. In many Asian countries of origin, amicable settlement of disputes is a culturally familiar and acceptable method for addressing grievances. See e.g. Farbenblum et al., supra note io at 82.

93. Migrant Workers and Overseas Filipinos Act of 1995, Rep. Act No. 8042, s. I0; Philippine Overseas Employment Administration, supra note 35 at Part II, Rule 2, s. I(f)(3).

94. Gordon, supra note $\mathrm{I} 8$ at $3 \mathrm{I}-2$.

95. Ibid. at 3I, citing author's interview with Jeriel Domingo, Philippines Overseas Employment Agency (POEA), Deputy Administrator and Officer in Charge, Adjudication and Licensing Regulation Office (22 July 20I4). 
to returned migrant workers, and also because the alternative is a prolonged and costly adversarial process. Indeed, of the 4,050 claims filed by workers in 2013, 3,000 were "resolved" through mediation before reaching the JSL adjudication mechanism..$^{96}$ As in Indonesia and Nepal, Filipino migrant workers are not entitled to free legal representation during these preliminary negotiations with recruitment agencies, and there are few sources of affordable legal assistance, ${ }^{97}$ raising significant questions about the true amicability and fairness of settlement outcomes.

It is clear from the discussion above that neither courts nor alternative dispute resolution programmes are systemically enabling migrant workers to enforce their contractual rights in relation to recruitment agencies. Current regulatory instruments do not adequately address the implementation and enforcement of laws regulating the content, execution, and enforcement of contracts. The lack of a migrant-centred approach to contractual regulation is similarly reflected in the failure to design contract oversight and enforcement mechanisms with the actual experiences, needs, and vulnerabilities of migrant workers in mind. In turn, this has left migrant workers un-empowered to demand, understand, or enforce their contractual rights, and has enabled recruitment agencies to continue to violate workers' legal rights with impunity.

\section{A RIGHTS-BASED APPROACH TO THE GOVERNANCE OF RECRUITMENT}

This section outlines the defining principles of a rights-based recruitment governance framework in countries of origin, ${ }^{98}$ and considers how such a framework might address the particular challenges to migrant worker protection within the recruitment regulatory contexts outlined above. Anticipating scepticism about the practical viability of a rights-based approach, this section goes on to identify a number of structural and practical barriers to enforcement of existing protective laws and policies, and illustrates how they could be addressed within the framework.

\section{A. Key Elements of a Rights-based Recruitment Governance Framework}

\section{Establishment of rights-holders and duty-bearers in law}

A rights-based approach to labour migration governance begins with a legally and socially entrenched conceptualization of migrant workers as rights-holders. Though it may sound tautological that regulations focused on migrant workers should be migrant-centric, in reality, such migrant-centric regulation remains uncommon in many countries of origin, where regulation of recruitment is still primarily directed to maximizing numbers and the efficiency of worker placement abroad. ${ }^{99}$

96. IOM, supra note 4 at $9 \mathrm{I}$.

97. Gordon, supra note $\mathrm{r} 8$ at $3 \mathrm{I}$. However, workers are entitled to representation at the subsequent stage of adjudication of claims within the JSL adjudication mechanism.

98. See supra note 8 regarding the derivation of the principles of the framework articulated in this paper.

99. See supra note 28. 
Therefore, a rights-based recruitment governance strategy must begin with the development of regulatory frameworks which place primary significance on the protection of migrant workers. This includes the establishment in law of specific rights held by migrant workers, and well-defined duties owed to migrant workers by the state and by recruitment agencies, individual sub-agents, and other private actors. State responsibilities should be clearly assigned under law to particular accountable government ministries or institutions, with delineated responsibility-sharing in the case of overlap. To enable enforcement and remedies for breaches, laws and regulations should establish the consequences for non-fulfilment of state and non-state actor responsibilities, such as those for a recruitment agency that fails to provide a worker in a timely manner with his or her contract or with mandated pre-departure information, as well as mechanisms through which those consequences are triggered.

Legal rights and responsibilities should reflect the realities of migrant workers' recruitment experiences. For example, laws regarding information that must be provided to prospective workers about positions abroad should account for the fact that workers often make the decision to migrate based on information provided by individual agents and brokers as opposed to recruitment agencies. ${ }^{\text {I0० }}$

Finally, if there is to be any realistic prospect of implementation, responsible actors must know and understand the content their obligations and how they ought to apply in practice. Both recruitment agencies and the government agencies overseeing them would benefit from clearer and more detailed information and training on their responsibilities, including guidance on forms of mandatory, permissible, and impermissible conduct. ${ }^{\text {IOI }}$ Such guidance can also be provided in the form of codes of conduct for the migrant worker recruitment industry ${ }^{\mathrm{IO} 2}$ that expand upon the content of core legal obligations. With respect to female migrant workers, the Committee on the Elimination of Discrimination Against Women (CEDAW) recommends that states "[r]equire recruitment agencies to participate in awareness-raising and training programmes and sensitize them on the rights of women migrant workers, the forms of sex- and gender-based discrimination, the exploitation women could experience and responsibilities of agencies towards the women". ${ }^{\text {103 }}$

\section{Enforcement of rights and responsibilities: ensuring transparency, accountability,} and access to remedies

A central tenet of a rights-based approach is the enforceability, and enforcement, of migrant workers' rights and the obligations of the state, as well as states' enforcement of the legal responsibilities of recruiters and other non-state actors. This requires the

\footnotetext{
Iоo. See supra Section II.A.2.

гог. IOM, supra note 4 at 8,50 , identifying Viet Nam's labour migration statue as an unual example of good practice in this respect.

I02. See e.g. Viet Nam Association of Manpower Supply, "Code of Conduct Applied to Vietnamese Enterprises Sending Workers for Overseas Employment”, online: ILO <http://www.ilo.org/wcmsp5/groups/ public/—ed_norm/—declaration/documents/publication/wcms_I45267.pdf $>$.

I03. General Recommendation No. 26 on Women Migrant Workers, United Nations Committee on the Elimination of Discrimination Against Women, UN Doc. CEDAW/C/2009/WP.I/R (5 December 2008), para. 24 (b)(iv) [CEDAW Gen. Rec. 26].
} 
development and adequate resourcing of necessary institutional infrastructure to enforce laws governing recruitment industry conduct, including ongoing monitoring and investigation-both routine and in response to migrant worker complaints. Institutions must also be capable of ensuring the accountability of agencies and individuals responsible for misconduct. This includes accountability for misinformation, for deception of workers in relation to salary and conditions of work abroad, ${ }^{104}$ and other fraudulent conduct such as charging of improper fees and costs. Under the UN Migrant Workers Convention, states are also required to prevent private agencies and others from confiscating workers' identity documents, and to ensure that workers can access remedies when this occurs. ${ }^{\text {I05 }}$ Similarly, accountability is critical for other kinds of non-monetary harm, such as physical confinement or abuse in recruitment agency training centres.

A rights-based approach also requires that states ensure non-repetition of rights violations by preventing agencies and individuals who repeatedly engage in such conduct from future involvement in the recruitment of migrant workers. This can be achieved by making renewal of recruitment licences contingent upon compliance with migrant protection responsibilities which extend beyond current basic corporate governance and financial solvency requirements, and by developing the institutional capacity necessary to conduct ongoing compliance audits. Resources should also be allocated to achieving greater transparency in licensing by ensuring that individuals associated with deregistered agencies cannot form new agencies, and making publicly available current lists of compliant and deregistered agencies. ${ }^{\text {Iо6 }}$

It is critical that such institutional processes and incentives operate as intended. In order to strategically regulate recruitment, countries of origin must understand the dynamic underlying conditions that drive or enable rights violations. In particular, they must understand and address migrant workers' lived recruitment experiences as well as recruitment business models. This includes developing an effective governance framework for sub-agents, ${ }^{\text {I07 }}$ as well as detecting and addressing unintended consequences of regulation and new business practices that emerge to circumvent regulation and that undermine rights protection. ${ }^{\text {I08 }}$ This requires rigorous data collection and analysis. For example, state parties to the UN Migrant Workers' Convention ${ }^{\mathrm{IO} 9}$ should be receiving, recording, and reporting information on migrant workers' experiences, particularly regarding travel, migration-related fees and debt,

\footnotetext{
I04. International Convention on the Protection of the Rights of All Migrant Workers and Members of their Families, I 8 December I990, 2220 U.N.T.S. 3 (entered into force I July 2003), art. 68, requires origin country governments to adopt measures against the dissemination of misleading information relating to emigration and immigration [Migrant Workers Convention].

I05. Ibid., arts. 21,83 .

I06. See also CEDAW Gen. Rec. 26, supra note 103, para. 24(b)(ii), recommending that states make available a list of authentic, reliable recruitment agencies.

I07. See supra Section II.A.3.

I08. For example, in response to the Philippines' establishment of a $\$ 400$ minimum wage for approval of domestic migrant worker contracts, some recruiters now require workers to sign two contracts-one stipulating a \$400 salary for government approval, and the "real" version with a lower wage. Other recruiters falsify the category of work, for example sending domestic workers on "service worker" visas that do not have a minimum wage. Jureidini, supra note I 5 at 88-9.

I09. Migrant Workers Convention, supra note I04.
} 
and issues of rights and access to justice. ${ }^{\text {I IO }}$ Data should be sufficiently detailed and disaggregated to enable a meaningful assessment of whether laws and policies are in fact protecting migrant workers ${ }^{\text {II }}$ - a process that does not appear to be currently taking place in many South and Southeast Asian countries of origin. ${ }^{\text {II } 2}$ The UN Committee on Migrant Workers also encourages states to develop systems for recording and reporting information on recruitment agencies, including through easily accessible web-based formats, focusing in particular on migrant worker complaints. ${ }^{\text {II } 3}$ Civil society organizations (CSOs) and trade unions have already undertaken innovative recruitment data collection and dissemination programmes, and can serve as valuable partners of the state in these efforts. ${ }^{\text {II } 4}$

Finally, a rights-based governance framework requires the creation of institutions and processes that enable and ensure that migrant workers can enforce their contractual and other legal rights. ${ }^{\text {II } 5}$ This includes ensuring that workers can obtain remedies both at home and abroad for violations of the obligations of government and the private sector, including remedies provided by recruitment agencies. ${ }^{\text {I } 6}$

Access to remedies requires more than just the mere existence of redress mechanisms. Under a rights-based governance approach, remedies must be meaningfully accessible in practice, in terms of geography, practical constraints, legal assistance, and transparent procedures. States must also ensure that migrant workers understand and are aware of procedures for accessing remedies. ${ }^{\text {II }}$ Redress must be

I Io. General Comment No.I on Migrant Domestic Workers, United Nations Committee on Migrant Workers, CMW/C/GC/I (23 February 20II), para. 62(d) [CMW Gen. Com. I]. Regarding data collection on recruitment-related harms and access to justice in practice, see Farbenblum et al., supra note Io at 85,9 I, I 57 .

I I . Concluding Observations: Mexico, United Nations Committee on Migrant Workers, CMW/C/MEX/ $\mathrm{CO} / 2$ (2OII), para. I8.

I I2. IOM, supra note 4 at 4 .

I I3. CMW Gen. Com. I, supra note I Io at para. 34 .

I I4. For discussion of ways in which CSOs and trade unions are able to enable better recruitment governance, see Patricia PITTMAN, "Alternative Approaches to the Governance of Transnational Labour Recruitment” (Fall, 20I5) International Migration Review at I 8-22.

I I 5. The Migrant Workers Convention and other human rights treaties require states to ensure that individuals seeking a remedy have their claim reviewed and decided by competent state judicial, administrative, legislative, or other authorities. See e.g. Migrant Workers Convention, supra note I04, art. 83(b). The World Bank defines access to justice more broadly as "[a]ccess by people, in particular from poor and disadvantaged groups to fair, effective and accountable mechanisms for the protection of rights, control of abuse of power and resolution of conflicts. This includes the ability of people to seek and obtain a remedy through formal and informal justice systems ... ." The World Bank, "A Framework for Strengthening Access to Justice in Indonesia”, online: World Bank < http://siteresources.worldbank.org/ INTJUSFORPOOR/Resources/A2JFrameworkEnglish.pdf $>$. For further discussion on the meaning of access to justice or access to remedies, see Paoletti et al., supra note Io at 32-3.

I 16. Migrant Workers Convention, supra note 104, art. 83. For recommendations on improving access to remedies, see generally Farbenblum et al., supra note ıо, and Paoletti et al., supra note ıо.

I I7. In fulfilment of arts. 3, 5, IO, and I4 of the Convention on the Elimination of All Forms of Discrimination Against Women, I8 December I979, I 249 U.N.T.S. I3 (entered into force 3 September I98I), States Parties should deliver or facilitate free or affordable gender- and rights-based predeparture information and training programmes that raise migrant workers' awareness and understanding of recommended contents of labour contracts, legal rights, and entitlements in countries of employment and procedures for invoking formal and informal redress mechanisms, among other things. CEDAW Gen. Rec. 26, supra note I03, para. 24 (b)(i). See also Migrant Workers Convention, supra note 104, arts. 33, 37 (obligation to provide all migrant workers (regular and irregular status) with information on their rights). 
timely, recognizing that compensation is needed immediately to remedy the economic strain of migration debt that saddles underpaid or injured workers and places them at risk of falling back into poverty. Redress mechanisms must also be grounded in migrant workers' legal rights, so that mediation and dispute-resolution schemes do not systemically result in recruitment agencies paying migrant workers less compensation than they are due by exploiting migrant workers' desperation for a timely payment. ${ }^{\text {II } 8}$ Remedies must be enforceable and subsequently enforced by state authorities when granted. ${ }^{\text {II } 9}$

\section{Migrant worker empowerment and participation}

Under a rights-based approach, the content and implementation of relevant laws and policies must also address the structural and multilayered vulnerability and exclusion of prospective, current, and returned low-wage migrant workers and their families. ${ }^{\mathrm{I}} \mathrm{O}$ It must emphasize their participation and empowerment throughout the migration process. ${ }^{\text {I2I }}$ For example, participation of migrant workers, civil society organizations, and trade unions is especially important in the context of the licensing and investigation of recruitment agencies. Such participation would enable those processes to better reflect agencies' treatment of migrant workers in practice. ${ }^{\text {I22 }}$

In order to enable migrant workers' participation and empowerment within governance regimes, states must also address information and power asymmetries between migrant workers and recruitment actors that create the conditions for abuse. In the longer term, this might involve states exploring the use of technology or other means to enable migrants to directly access the job market and other information, as well as exploring governmentto-government recruitment schemes to decrease reliance on recruitment intermediaries. In the immediate term, this requires addressing the vulnerabilities of particular groups of migrant workers, including women, when regulating workers' access to information pre-departure and while abroad, in order to prevent rights violations. Provision of information to prospective migrant workers is a core state obligation under the Migrant Workers Convention, and applies to all prospective, current, and returned migrant workers regardless of whether they travel through regular or irregular migration channels. ${ }^{\text {I23 }}$ Critically, states must ensure that every migrant worker receives and understands his or her recruitment and employment contract before agreeing to work abroad, and that workers and their families retain copies of those contracts.

\section{Incorporation of international human rights and labour rights standards}

According to the UN Office of the High Commissioner for Human Rights, a human rights-based approach is one that provides practical guidance and concrete tools to

\footnotetext{
II 8. See supra notes $84-98$ and accompanying text.

I 19. Migrant Workers Convention, supra note I04, art. 83 (c).

I20. The Migrant Workers Convention defines migrant workers to include prospective and returned workers, and the Convention applies to workers' families. See supra note I04, arts. I, 2.

I2I. Ndiaye, supra note 8 .

I22. See supra notes $30-36$ and accompanying text regarding migrant worker participation in licensing processes.

I23. Migrant Workers Convention, supra note I04, arts. 33, 37.
} 
enable states to implement the fundamental normative principles contained within the human rights legal framework. ${ }^{124}$ In the labour migration context, this legal framework incorporates core labour rights, ${ }^{\mathrm{I} 25}$ human rights, ${ }^{\mathrm{I} 26}$ and anti-trafficking ${ }^{\mathrm{I} 27}$ conventions, supplemented by a range of relevant non-binding UN and International Labour Organization (ILO) instruments as well as key non-binding subregional instruments. ${ }^{\text {I28 }}$ Collectively, these instruments provide migrant workers with rights that are specific to the labour migration context, ${ }^{\mathrm{I} 29}$ as well as general rights to equal treatment, to due process before the law, and to remedies for rights violations, among others. ${ }^{\mathrm{I} 30}$

A number of international legal instruments and non-binding regional instruments $^{\mathrm{I} 3 \mathrm{I}}$ directly address states' obligations with respect to migrant worker recruitment. For example, the 20I4 ILO Protocol to the Forced Labour Convention requires states to prevent abusive practices in recruitment and to ensure migrant workers' access to appropriate and effective remedies, including compensation. ${ }^{132}$

I24. UNOHCHR, supra note 6.

I 25. For an overview of the ILO Conventions and policy recommendations relevant to migrant workers, see Judy FUDGE, "Precarious Migrant Status and Precarious Employment: The Paradox of International Rights for Migrant Workers" (2OI2) 34 Comparative Labour Law and Policy IOI-37, and Fay FARADAY, "Profiting from the Precarious: How Recruitment Practices Exploit Migrant Workers", Metcalf Innovation Fellowship, Metcalf Foundation, April 20I4 at 48-9.

I26. For a list of relevant human rights treaties, see Farbenblum et al., supra note Io at I6I-2.

I27. See e.g. Palermo Protocol, supra note I8, art. 3, incorporating recruitment within the trafficking definition.

I28. See e.g. ASEAN Declaration on the Protection and Promotion of the Rights of Migrant Workers Issued at the I 2th ASEAN Summit (January 2007), online: ASEAN < http://www.asean.org/communities/aseanpolitical-security-community/item/asean-declaration-on-the-protection-and-promotion-of-the-rights-ofmigrant-workers-3> [ASEAN Declaration], and Dhaka Declaration of Colombo Process Member Countries (20I I), online: International Organization for Migration <https://www.iom.int/jahia/webdav/ shared/shared/mainsite/microsites/rcps/colombo/Colombo-Process-Dhaka-Declaration.pdf $>\quad[D h a k a$ Declaration], focused on migration with dignity, adopted by the Colombo Process, a regional ministerial consultation process on labour migration for countries of origins in Asia.

I 29. See e.g. Migrant Workers Convention, supra note I04, and CEDAW Gen. Rec. 26, supra note I03.

I30. See e.g. International Covenant on Civil and Political Rights, I6 December I966, 999 U.N.T.S. I7 I (entered into force 23 March 1976), arts. 2, 14, 26; International Covenant on Economic, Social and Cultural Rights, I6 December 1966, 993 U.N.T.S. 3 (entered into force 3 January 1976), arts. 2, 3; and CEDAW, supra note II7, arts. 2, 3, I5.

I3 I. Recruitment has been a focus of several regional dialogues on labour migration within Asia, though none have resulted in formal agreements to date besides the non-binding ASEAN Declaration on the Protection and Promotion of the Rights of Migrant Workers, which contains limited reference to human rights but obligates origin country Member States to "[e]stablish and promote legal practices to regulate recruitment of migrant workers and adopt mechanisms to eliminate recruitment malpractices through legal and valid contracts, regulation and accreditation of recruitment agencies and employers, and blacklisting of negligent/unlawful agencies”. ASEAN Declaration, supra note I28, art. I4. See also Dhaka Declaration, supra note I28; Abu Dhabi Dialogue, a collaboration among origin and destination countries to address development in temporary labour mobility in Asia which has among its focus areas the prevention of illegal recruitment, International Organization for Migration, "Abu Dhabi Dialogue" (2008), online: International Organization for Migration <https://www.iom.int/abu-dhabi-dialogue>; and the ASEAN Forum on Migrant Labour, which in $20 \mathrm{I} 2$ carried the theme "Towards effective recruitment practices and regulations", online: ILO <http:/www.ilo.org/asia/whatwedo/events/WCMS_209467/lang-en/ index.htm $>$.

I32. Protocol of 2014 to the Forced Labour Convention I930, I I June 20I4, ILO No. Po29 (entered into force 9 November 20I6), arts. 2(d), 4(I), online: <http://www.ilo.org/dyn/normlex/en/f?p=NORMLEXPUB:I2100:०::NO::Pı210о_ILO_CODE:Po29>. See also ILO Private Employment Agencies Convention, supra note 3, and Private Employment Agencies Recommendation 1997, I9 June 1997, ILO 
The associated 20I4 ILO Forced Labour Recommendation sets out relevant measures that states should undertake, including ensuring that workers receive detailed and transparent contracts, and establishing adequate and accessible complaints mechanisms. ${ }^{\text {I33 }}$ The 20I I ILO Domestic Workers Convention similarly requires states to "ensure that adequate machinery and procedures exist for the investigation of complaints, alleged abuses and fraudulent practices concerning the activities of private employment agencies in relation to domestic workers". ${ }^{134}$ Most South and Southeast Asian countries of origin have not yet ratified the Forced Labour Protocol and other key ILO instruments that directly address recruitment. ${ }^{35}$ However, the Protocol is relevant to states' obligations regarding the prevention of forced labour under the underlying ILO Forced Labour Convention, to which most countries of origin are parties. $^{\text {I36 }}$

A number of UN human rights treaties also establish obligations and guidance to states on migrant worker recruitment, and have been more widely ratified by Asian countries of origin than relevant ILO instruments. For example, the Migrant Workers Convention, ratified by four major South and Southeast Asian countries of origin, ${ }^{\mathrm{I}} 37$ requires states to effectively license, regulate, supervise, and monitor recruitment agencies, brokers, and other intermediaries to ensure they respect the rights of migrant workers. ${ }^{\text {I } 8}$ This includes establishing a range of formal, regular, transparent, and state-regulated mechanisms for supervising recruitment, among other things. ${ }^{\text {I39 }}$ Though it does not explicitly address migrant recruitment, the widely ratified Convention on the Elimination of All Forms of Discrimination Against Women has been interpreted by its supervising treaty body as requiring States Parties to regulate and monitor recruitment, and to provide training and other protective measures in

No. ı 88, online: ILO <http://www.ilo.org/dyn/normlex/en/f?p=NORMLEXPUB: 5 5:0:::5 5 :P55_TYPE, $\mathrm{P}_{55}$ _LANG,P55_DOCUMENT,P55_NODE:SUP, en, RI 88,/Document $>$, for state obligations regarding supervision of private recruitment agencies.

I33. 2014 ILO Forced Labour Recommendation, supra note I4, art. 8.

I34. Convention Concerning Decent Work for Domestic Workers 201 I, I 6 June 20 I I, ILO No. I 89 (entered into force 5 September 20I3), online: ILO <http://www.ilo.org/dyn/normlex/en/f?p=I000:I 2 I00:0:: NO::PI2100_ILO_CODE:Ci $89>$, art. I $5(\mathrm{I})(\mathrm{b})$.

I35. See e.g. Convention Concerning Migration for Employment (Revised) I949, I July I949, ILO No. 97 (entered into force 22 January I952), online: ILO <http://www.ilo.org/dyn/normlex/en/f?p=NORMLEXPUB:I 2 I00:०::NO::PI2I00_INSTRUMENT_ID:3 I2242>, ratified only by the Philippines and Malaysia-Sabah; ILO Private Employment Agencies Convention, supra note 3, with no ratifications in region; Convention Concerning Work in the Fishing Sector 2007, I4 June 2007, ILO No. I88, with no ratifications in region; and Convention Concerning Decent Work for Domestic Workers 20II, supra note I34, ratified only by the Philippines. The Maritime Labour Convention 2006, 23 February 2006 (entered into force 20 August 2013), which addresses recruitment of migrant worker seafarers, has been more widely ratified in the region. See ILO, "Information on Implementation of MLC by Country", online: ILO <http://www.ilo.org/dyn/normlex/en/f?p= I000:80020:0::NO:80020>.

136. Convention Concerning Forced or Compulsory Labour, supra note I8. For ratifications, see ILO, "Ratifications of Co29 - Forced Labour Convention, I930 (No. 29)", online: ILO <http://www.ilo.org/ dyn/normlex/en/f?p=NORMLEXPUB:I I $300: 0:: N O:: P$ I I $300 \_I N S T R U M E N T \_I D: 3$ I 2 I $74>$.

I37. Bangladesh, Indonesia, the Philippines, and Sri Lanka. Cambodia has signed but not ratified the Convention.

I3 8. Migrant Workers Convention, supra note I04, art. 66; CMW Gen. Com. I, supra note I Iо, para. 33.

I39. CMW Gen. Com. I, supra note I Io, paras. 34 (a)-(d). The General Comment refers specifically to the rights of migrant domestic workers but the suggested examples would logically apply to all migrant workers. 
order to fulfil women migrant workers' fundamental human rights. ${ }^{\text {I40 }}$ This includes the decentralization of training and other services in order to fulfil obligations to women in rural areas. ${ }^{\mathrm{I}}{ }^{\mathrm{I}}$

Migrant workers' testing and enforcement of their convention rights in relation to countries of origin have generally remained limited within international forums. ${ }^{\mathrm{I} 42}$ Nevertheless, states are receiving increasingly detailed practical guidance on the implementation of their treaty obligations from the ILO and the human rights treaty bodies that can support the application of a rights-based governance framework in practice. This includes General Comments specific to particular groups of migrant workers such as women and workers in an irregular status, ${ }^{\mathrm{I}}{ }^{3}$ as well as Concluding Observations to particular states under various human rights treaties that evaluate migrant worker recruitment laws and practices and make recommendations for reform. $^{\text {I44 }}$

\section{B. Overcoming Structural and Practical Impediments to Enforcement}

Sceptics may reasonably question whether a rights-based approach to governance can have an impact in countries of origin beyond hortatory inspiration, given that many protective laws already exist in these countries and are not enforced, and that non-compliance with current laws is often driven by entrenched structural and commercial forces operating transnationally. This section tackles each of these challenges by identifying key obstacles to enforcement, and by indicating ways in which the proposed framework can in fact enable more effective solutions than are available via current approaches.

\section{Transnational structural drivers of non-compliance and inflated recruitment costs}

Oversight of recruitment is undermined by structural forces that drive non-compliance, undermining protection and fulfilment of migrant workers' rights. These forces include a dense nesting of poverty and unemployment at home, wage differentials between origin and destination countries, the oversupply of migrant labour compared with the demand in low-wage industries, ${ }^{\mathrm{I} 5}$ large numbers of recruitment intermediaries

\footnotetext{
I40. CEDAW Gen. Rec. 26, supra note I03, para. 24.

I4I. Ibid.; CEDAW, supra note II7, art. I4.

I42. Individual complaints to the treaty bodies in relation to migrant workers remain conspicuously scarce, particularly when compared with the myriad cases on asylum seekers and others in need of international protection. See Vincent CHETAIL, "The Committee on the Protection of the Rights of All Migrant Workers and Members of Their Families" in Philip ALSTON and Frédéric MEGRET, eds., The United Nations and Human Rights: A Criticals Appraisal, 2nd ed. (London: Oxford University Press, 20I4), at $\mathrm{I} 4$.

I43. See e.g. CMW Gen. Com. I, supra note I Iо; General Comment No. 2 on the Rights of Migrant Workers in an Irregular Situation and Members of Their Families, United Nations Committee on Migrant Workers, UN Doc. CMW/C/GC/2 (28 August 20I3); CEDAW Gen. Rec. 26, supra note I03.

I44. See e.g. Concluding Observations on the Second Periodic Report of the Philippines, UN Committee on Migrant Workers, UN Doc. CMW/C/PHL/CO/2 (I May 20I4); Concluding Observations: Indonesia, UN Committee on the Elimination of Discrimination Against Women, UN Doc. CEDAW/C/IDN/CO/6-7 (7 August 20I2), paras. 43-4. The Universal Periodic Review process may also provide a form for examining application of human rights principles to the governance of migrant worker recruitment.
}

I45. Baruah, supra note 33 at 42 . 
competing for a limited supply of overseas jobs, and a business culture in which employers and their suppliers do not expect to bear the costs of recruiting low-wage migrant workers. These factors create fertile ground for deceptive and extortionate conduct throughout the transnational migrant labour recruitment web. In particular, they enable destination country recruiters and employers to demand fees, bribes, and kickbacks from their origin country counterparts (or directly from workers themselves) ${ }^{\mathrm{I} 46}$ in order to obtain access to jobs for which recruitment agencies compete across Asia and globally. This commonplace extortion is fuelled by charges passed down the recruitment chain to workers, undermining the commercial competitiveness of "ethical" origin country recruiters that do not charge workers fees, pay bribes to destination country agents, or require the end user in the destination country to bear the costs of migrant recruitment. This situation is replicated in the relationships between origin country recruitment agencies and individual sub-agents at the village level, who compete for access to overseas jobs and commissions that local recruitment agencies control. ${ }^{\mathrm{I}} 47$

This context presents significant obstacles to the elimination or substantial reduction of recruitment fees, ${ }^{148}$ including the need for transnational structural reforms to migrant worker recruitment and employment business models. Such reforms must involve government ${ }^{\mathrm{I} 49}$ and industry in destination countries, and are difficult if not impossible for countries of origin to implement alone.

Attempts at innovative reform are beginning to take place in destination countries. These include anti-trafficking and anti-forced labour initiatives by a variety of multinational companies ${ }^{150}$ and state procurers of goods and services, ${ }^{15 \mathrm{I}}$ which require that no actor in their supply chain charge migrant workers fees. These schemes could create a market for non-fee-charging recruitment agencies in countries of origin, realistically enabling countries of origin to enforce their legislated fee limitations. However, the schemes can only succeed if industry expectations are transformed and destination country corporations and state procurers expect to bear the legitimate costs of recruiting low-wage migrant workers, as they already do for mid- and high-wage foreign workers. ${ }^{\mathrm{I}}{ }^{2}$

\footnotetext{
I46. Jureidini, supra note I 5 at 44 .

I47. See supra Section II.A.3.

148. See supra notes I4-I9 and accompanying text regarding impact of fees on rights protection.

I49. Under the Migrant Workers' Convention, countries of origin, transit, and destination share responsibility for regulating and monitoring recruitment and placement processes. CMW Gen. Com. I, supra note I IO, para. 3 I.

I 50. See e.g. Hewlett Packard, "HP Supply Chain Foreign Migrant Worker Standard” (Io November 20I4), online: Hewlett Packard <www.hp.com/hpinfo/globalcitizenship/environment/pdf/Foreign-MigrantWorker-Standard.pdf > at para. 2, stating that " $[\mathrm{c}]$ ontracts shall explicitly prohibit the charging of fees to potential foreign migrant workers by either the recruitment agents or any sub-agents".

I 5 I. See e.g. Qatar Foundation, “QF Mandatory Standards of Migrant Workers' Welfare for Contractors and Sub-Contractors" (2013), online: Qatar Foundation <http://www.qf.org.qa/app/media/2379> at 5I; United States Exec. Order No. 13627, 77 Fed. Reg. 60029 (Sept. 25, 201 2); California's Foreign Labor Recruitment Law, S.B. 477, 2013-4 Sess (Cal. 2013).

I 52 . This includes transparently incorporating recruitment costs into tendering processes so that suppliers that pass legitimate costs of recruitment on to the government or commercial end user (rather than charging migrant workers) are not disadvantaged. The author is not aware of evidence that this has taken place with state procurement schemes or commercial codes at the time of writing. If end users truly absorb
} 
Industry reform must also be underpinned by governance initiatives ${ }^{\mathrm{I} 53}$ in countries of destination and origin to commercially incentivize regulatory compliance, and to systemically penalize misconduct. To this end, scholars have recommended joint liability regimes that make beneficiaries of migrant labour responsible for misconduct in recruitment within their supply chain. ${ }^{154}$ Though driven from the destination country, such approaches will only work when regulation is effective in countries of origin: employers in destination countries are only able to ensure that their suppliers are not charging fees if, in fact, a market of non-fee-charging agents exists in countries of origin and is effectively monitored by those governments, all the way down to the village level. Therefore, countries of both origin and destination have indispensable roles to play in overcoming present obstacles to recruitment fee elimination through governance frameworks that transform recruitment business models. These may be reflected or initiated through bilateral agreements between countries of origin and employment. ${ }^{\text {I5 }}{ }^{5}$

Finally, there may be opportunities for countries of origin and destination to address fee charging more transparently and systematically by addressing statutory and contractual governance of the transnational commercial relationships between recruitment and placement agencies in countries of origin and destination. ${ }^{156}$ This is an area that has received particularly limited consideration within the scholarly literature, and is rarely addressed within bilateral agreements entered into by Asian countries of origin $^{157}$ as money continues to change hands across borders in a manner that is opaque and underregulated.

\section{Local structural and practical challenges to enforcement within countries of origin}

Transnational structural challenges related to perverse fee incentives for the various actors are not the only barriers to the implementation of a rights-based recruitment governance framework. There are numerous other practical and political obstacles which impede recruiter accountability and undermine migrant worker empowerment

recruitment costs, consumers may also need to accept that a small portion of the fees previously paid by workers will be passed along in the form of increased costs of goods and services.

I 53. Though important, corporate brand sensitivity cannot drive these transformations alone because it is only as powerful as the audits and social pressure that drive it, and it may not be a motivating factor in industries that are not populated by familiar brands, or in domestic work.

I 54. For example, in Canada, the Manitoba Worker Recruitment and Protection Act 2008 bars recruiters from charging fees to workers, and employers from passing along those costs to their migrant worker employees. It requires employers to use only government-registered recruitment agencies, and employers can be compelled to reimburse workers for recruitment charges levied by suppliers. Faraday, supra note I 25 at 69-75. For further examples of joint liability schemes, see Gordon, supra note I 8 at 22-32.

I 55. For examples of bilateral agreements that prohibit recruitment fees and related salary deductions, see IOM, supra note 4 at 60.

I 56 . Indonesia has taken promising steps to formally vet and govern these relationships. For example, it passed a regulation in 2013 that sets minimum standards and accreditation procedures for partner recruitment agencies in destination countries, though implementation and enforcement remain a challenge. Farbenblum et al., supra note Io at 44-50. It also requires Indonesian recruitment agencies to enter into a contract with their partners in the destination country (placement agencies or employers) which must be vetted by the embassy in the destination country as a condition for government permission to recruit for that position. Ministry of Manpower and Transmigration Regulation 22/2014 (Id.), art. 3.

I 57. IOM, supra note 4 at 7 . 
and rights protection that, in contrast to fee elimination, can be unilaterally addressed by countries of origin.

First, countries of origin can take a more systematic, co-ordinated, and transparent approach among government ministries and institutions responsible for oversight of recruitment and migrant protection. This includes better integrating the services and responsibilities of foreign affairs ministries, labour or manpower ministries, and specialized labour migration bodies, as well as law enforcement agencies with jurisdiction over the investigation and prosecution of labour trafficking cases. In numerous countries of origin, current jurisdictional and functional overlaps and gaps among these institutions and between levels of government (national, state, local) result in diminished oversight of recruitment actors and weaker protection and support for migrant workers to enforce their rights. ${ }^{\text {I5 } 8}$

Countries of origin can also ensure that institutions tasked with overseeing recruitment and handling of worker claims are adequately resourced, and that they have the capacity, procedures, support schemes, and expertise necessary to ensure that migrant workers can meaningfully access remedies against recruitment agencies, ${ }^{\text {I59 }}$ and/or access insurance payouts to which they are entitled. ${ }^{160}$ States can ensure that government pre-departure services and redress mechanisms address worker experiences and vulnerabilities, and are effectively decentralized and accessible to the vast majority of migrants who live far from the capital. ${ }^{\text {6I }}$ They can also ensure that recruitment agency licensing is linked with migrant worker protection, and accompanied by procedures that are transparent and robust, and which engage migrant workers in decision-making and outcomes. ${ }^{\text {I62 }}$ Compliance with licensing conditions can be enhanced by introducing, alongside penalties for non-compliance, regulatory incentives for recruitment agencies that comply with (or go beyond) minimum protection requirements contained in regulations or in industry self-regulation codes or independent monitoring frameworks. For example, agencies could be offered rewards such as streamlined licence extensions, waivers of certain compliance requirements, tax incentives, expedited processing of employment contracts, public listing as a recommended agency, reduced monitoring supervision after a period, or offers to fill quotas under bilateral agreements. ${ }^{163}$

I 5 8. See e.g. Farbenblum et al., supra note io at I30; Paoletti et al., supra note Io at 84-5, I6I.

I59. These are currently major impediments to accountability and redress in many, if not all, origin countries. See e.g. Paoletti et al., supra note Io at 95, and Farbenblum et al., supra note Io at $\mathrm{I} 4 \mathrm{I}-2$.

I60. For discussion and detailed recommendations concerning migrant workers' access to home-based insurance schemes, see Farbenblum et al., supra note Io at 85-99, I 52-3.

I6I. See supra Section II.A.2.

I62. See supra Section II.A.I. The UN Committee on Migrant Workers has suggested that States Parties to the Migrant Workers Convention fulfil their obligations regarding recruitment regulation by establishing, in consultation with migrant worker organizations, specific criteria relating to migrant domestic workers' rights, and ensuring that only agencies observing these criteria can continue to operate. CMW Gen. Com. I, supra note I Io, para. 35 .

I63. International Labour Organization and the Asian Research Center for Migration, Chulalongkorn University, "Regulating Recruitment of Migrant Workers: An Assessment of Complaint Mechanisms in Thailand" (2013) at I6. See also Beate ANDREES, Alix NASRI, and Peter SWINIARSKI, "Regulating Labour Recruitment to Prevent Human Trafficking and to Foster Fair Migration: Models, Challenges 
On a related note, states can better target government services and oversight to address the different recruitment experiences and vulnerabilities of certain groups of migrant workers, including female workers and workers travelling along particular migration corridors or working in particular sectors, consistent with non-discrimination obligations and state responsibilities to ensure women's attainment of substantive equality. ${ }^{\text {.64 }}$ For example, local branches of Indonesian national government ministries have important oversight functions concerning recruitment, but they have historically failed to oversee the recruitment process for the particularly vulnerable group of workers from poor communities going to the Middle East (mostly women), because Middle East recruitment agencies are based only in the capital, Jakarta, and have no local presence. ${ }^{\mathrm{I} 5}$

Countries of origin can develop oversight and accountability mechanisms for sub-agents that more effectively protect migrant workers by ensuring that such frameworks reflect the realities and diversity of migrant workers' actual recruitment experiences, and are designed to promote systemic accountability, non-repetition of harms, and access to remedies. This includes taking into account the impact on governance of, for example, the social ties that many migrant workers have with their respective sub-agents. As noted in Section II.A.3 above, it is possible that the Nepalese model, or an alternative model, ${ }^{166}$ could be designed, implemented, and enforced in a manner that achieves these goals. Further research and pilot projects are required to determine the form of regulatory model(s) that would most effectively ensure accountability and worker protection in relation to sub-agents, and how such a model ought to be operationalized and enforced in the light of migrant worker experiences. Given the commonality of this challenge across South and Southeast Asia in particular, this is an area that would especially benefit from collaborative approaches to research and development of good practice among countries of origin.

To address the inevitable limitations in foreign employment laws and their implementation, countries of origin can also examine the role that other areas of domestic law can and should play in a rights-based approach to the regulation of recruitment and labour migration more broadly. These include rights, responsibilities, and remedies under employment and workplace law, immigration law, criminal law (including general crimes

and Opportunities" (2OI 5 ) at 65, online: ILO < http://www.ilo.org/global/publications/working-papers/ WCMS_3778I3/lang-en/index.htm>, providing the example of Jordan, which has recently enacted a framework for a three-tiered rating system for private employment agencies in which higher ratings will translate into lower bank deposit requirements.

I64. CEDAW, supra note I I7, arts. I, 2.

165. Farbenblum et al., supra note Io at 6I. See also supra notes 37-8 and 49-55 and accompanying text.

I66. A proposed "Code of Ethics" for recruitment agencies in Sri Lanka requires agencies to "instruct and administer [local sub-agents] to ensure that they comply with the laws of the country and hold them liable for the recruitment of workers, including losses to workers". Association of Foreign Employment Agents, "Code of Ethics for Recruitment Agents Employing Migrant Workers" (September 201 2) (unpublished draft), art. 5 (ix) cited in Jureidini, supra note I 5 at 67 . Taking this idea a step further, a more formal regulatory option would be for states or industry bodies to create an independent licensing or approval system for sub-agents that could be used as part of an incentive scheme, whereby agencies would be automatically liable for sub-agents' conduct but agencies that use licensed sub-agents may receive immunity from liability under certain conditions, and workers and/or government could hold the subagent directly accountable. This may appeal to destination country employers that are brand-sensitive or are legally obliged to comply with recruitment standards, but that struggle to effectively conduct due diligence on recruitment businesses in migrant workers' home countries. 
such as fraud, as well as specific anti-trafficking laws), contract law, commercial law, financial and lending regulatory law, insurance law, industry-specific laws (including laws regulating travel agencies, transport companies, medical examination providers, and training service providers), and potentially consumer protection law in relation to misleading or deceptive information provided to prospective migrant workers. Each of these areas of law offers further potential to give content and force to the rights of migrant workers in contexts in which law, processes, institutions, and expectations of enforcement may be more robust than in the foreign employment arena.

Finally, countries of origin can institute measures to tackle corruption and collusion at various levels of government and the recruitment industry that undermine accountability. Most of the countries from which migrant workers originate are developing countries that lack robust judiciaries, government transparency, and entrenched rule of law principles to guard against corruption. This presents formidable obstacles to the enforcement of a rights-based recruitment governance framework, as migrant worker protection continues to be significantly undermined by systemic corruption and collusion between recruitment agencies and government, and by collusion between recruitment agencies and other merchants of labour in the destination country and at the village level at home. For example, in March 20I4 the Cambodian Labour Minister announced that promising new recruitment agency regulations will be enforced and that inspections will be conducted. ${ }^{167}$ The manager of a Malaysian-owned recruitment agency operating in Cambodia reportedly responded: "As we know, in Cambodia, everything can be bought. None of the local [recruitment] agencies will fail the inspection-they know how to do business.” ${ }^{68}$

Corruption is a complex and systemic phenomenon that requires broad anti-corruption programmes and the political will to tackle its pervasive influence. However, there are specific measures to reduce corruption within the recruitment industry that-focused on relevant agents, processes, and incentives for realizing rights-are not complex to introduce, and would have a significant effect. For example, the Philippines prohibits government officials and their families from holding financial interests in recruitment agencies as a condition for licensing, ${ }^{169}$ and prohibits recruitment agency directors from involvement in the management of a travel agency. ${ }^{170}$ Measures may also include disintermediation initiatives that enable migrant workers to access job information and services directly online, ${ }^{17 \mathrm{I}}$ reducing

I67. See supra note 27.

I68. Matt BLOMBERG, "Labour Ministry to Inspect Migrant Worker Recruitment Agencies” The Cambodia Daily (26 March 20I4), online: The Cambodia Daily <https://www.cambodiadaily.com/archives/labourministry-to-inspect-migrant-worker-recruitment-agencies-54925/>.

I69. See e.g. Philippine Overseas Employment Administration, supra note 35, Part II, s. 2(e). Commercial interests in recruitment businesses are often openly held by government officials, even at the most senior levels. See Roshan SEDHAI, “Agents Add to Nepali Migrants' Expenses” eKantipur (I 5 March 20I 5 ), online: eKantipur <http:/www.ekantipur.com/2015/03/I 5/top-story/agents-add-to-nepali-migrantsexpenses/402833.html>, observing that Nepalese State Minister for Labour Tek Bahadur Gurung owns a recruiting agency.

I70. Migrant Workers and Overseas Filipinos Act of 1995, Rep. Act No. 8042, s. 6(j).

I7I. See supra Section II.A.3, discussing migrant worker participation and empowerment. Though technology will not be accessible to all migrant workers, it will likely be accessible to a substantial number of aspiring migrants in the very near future. "Planet of the Phones" The Economist (28 February 201 5), online: The 
opportunities for corruption and forcing recruiters to compete for transparency and the quality of services they provide. Migrant workers' access to technology may also reduce fraud and corruption issues related to the withholding, falsification, and substitution of migrant workers' contracts and identity documents.

Ultimately, overcoming any of these obstacles will depend on political will within the countries of origin. Though corruption certainly contributes to weak political will to meaningfully address misconduct in recruitment, it is not the only factor. Countries of origin compete with each other for access to labour markets and remittance opportunities abroad, and may be reluctant to undermine their desirability as a worker source country if they enforce recruitment restrictions that make recruitment from their country more difficult for employers. ${ }^{172}$ Even when there is political will for stronger governance, there are limited resources available in developing countries for the enforcement of recruitment regulations amid competing domestic priorities.

However, even on purely economic terms, political will for a rights-based recruitment governance framework may be strengthened by promoting the strong national interest in reducing the social and economic costs of abusive recruitment practices that impede sustainable development. These include the long-term economic costs to migrant workers, their families, communities, and indeed the national economy of inflated fees paid to private recruiters and related high-interest debt, of receiving wages (and remittances) lower than those promised to the worker when she decided to migrate at significant cost, and of having no accessible means for seeking compensation for those losses. These financial costs sit alongside the social and economic burden of unremedied physical and psychological injuries sustained abroad as a result of abusive recruitment practices or inadequate preparation for migration, often with long-term consequences for the worker's future earning capacity and social relationships. Studies which quantify these costs and demonstrate the scale of recruitment abuses may increase political will to institute rights-based reforms, as opportunities to access the expanding marketplace of jobs within transnational supply chains requires fair recruitment practices.

These economic bases for reform may lend support to both law-makers and policy-makers who are already championing reform. ${ }^{173}$ Indeed, within most if not all countries of origin, there are growing pockets of political will for reform that can be supported and expanded, particularly if accompanied by increased popular support for

Economist <http://www.economist.com/news/leaders/2 I 645 I 80-smartphone-ubiquitous-addictive-andtransformative-planet-phones $>$, estimating that, by 2020 , eighty percent of the adult population in the world will own a smartphone.

I72. The prospect of losing access to remittances is also a disincentive to countries of origin enforcing rights of their migrant workers in the country of employment. See e.g. Rohini MOHAN, "As Migrants Slave in Gulf, India is Stuck Choosing Between Worker Rights and Remittances" The Economic Times (I9 November 20I 5), online: The Economic Times <http://articles.economictimes.indiatimes.com/20I 5I I-I9/news/684I2275_I_gulf-countries-human-rights-watch-migrant-workers $>$.

173. For example, the Asian Inter-Parliamentary Caucus on Labour Migration (AIPCLM) is a group of law-makers and their staff from across Asia that has among its aims to "promote the cause of migrant workers in our respective national parliaments; to collectively engage at the regional and international levels in the development of agreements and legislation; [and] to acknowledge the need to consider national, economic, and human security in the management of migration issues". AIPCLM, "About Us", online: AIPCLM <asianparliamentarians.mfasia.org/who-we-are>. 
fairer recruitment practices. This is a longer-term challenge for migrant worker advocates who could be aided by a change in public discourse and media coverage beyond harms perpetrated against origin country nationals by employers abroad, to focus on abuses inflicted or enabled at home, and the personal as well as systemic social and economic impact of failures to adequately address them.

\section{CONCLUSION}

A rights-based framework for labour migration governance has the potential to significantly improve migrant worker protection and the accountability of state and non-state actors for rights violations. Presently, while the tendency of scholars and states has been to focus on destination countries, this paper has articulated why any such framework must take into account the fact that every labour migration story begins and ends at home, in migrant workers' countries of origin-and much that is protective and enabling of migrant workers can be achieved in these contexts.

All countries of origin in South and Southeast Asia have developed laws, regulations, policies, and contractual frameworks to govern migrant worker recruitment. Yet, as this paper and the new empirical studies it references illustrate, in the absence of a migrant-centred and rights-based approach to regulation, these legal instruments often fail to adequately protect migrant workers and to prevent misconduct in recruitment. They are equally failing to achieve accountability within the recruitment industry and to provide workers with remedies when their rights are violated. Even the best designed of these instruments are often not implemented and enforced by governments, and the burden placed on migrant workers to enforce their contractual rights and the obligations of relevant private actors cannot be met.

A rights-based recruitment governance framework is neither a panacea that will end all ills overnight. Nor does it simply involve the creation of rights and obligations under law-though this is a critical component. Rather, it provides a lens through which the impact of governance frameworks on vulnerable migrant worker groups can be better understood and addressed. Viewed through that lens, countries of origin would observe, for example, that the actual recruitment experience of many workers differs from the hypothetical experience on which laws and policies are based, including the central role played by unaccountable individual sub-agents at the village level. Countries of origin would appreciate the overwhelming importance of timely and full compensation, as well as other remedies to migrant workers who have been underpaid or mistreated abroad, and who risk falling back into poverty upon their return home. Additionally, countries of origin would recognize the limited value of redress mechanisms that are practically inaccessible (due to factors such as cost, geography, and lack of legal assistance), ineffective (for example, due to skewed power relationships and lack of decision-maker expertise), or that do not enable workers to obtain timely payment from recruitment agencies or insurers (typically due to poor institutional processes, inadequate resourcing, and lack of oversight).

Countries of origin would also recognize where the agency of potential and current migrant workers could be drawn on and supported to powerful effect. Such states 
would observe, for instance, that migrant workers and their families and representatives know the most about the performance of particular recruitment agencies and sub-agents, and could contribute information to the licensing, investigation, and oversight of the recruitment industry that would ensure better protection and accountability if such processes were transparent and allowed for workers' participation.

Countries of origin would understand the importance of ensuring that migrant workers receive the information they need before departure, while abroad, and upon their return, in order to understand their legal rights and be in a position to enforce them. This includes ensuring that workers receive and understand their recruitment and employment contracts before they decide to migrate abroad, and that copies of those documents are readily available to workers and their families throughout the migration process. It also includes ensuring that job-related information provided to migrant workers by sub-agents and recruitment agencies is correct, and that recruitment agencies and individual sub-agents are held accountable to migrant workers and the state for deliberate misinformation or deception about salary or other conditions of work, as well as for improper fee-charging.

There are certainly formidable challenges to the implementation and enforcement of rights-based recruitment governance frameworks in migrant workers' countries of origin, not least the need for transnational collaboration with destination countries on efforts to restructure recruitment business models in order to eliminate recruitment fees and bribery. Nevertheless, this paper has elaborated a range of measures within the jurisdiction and control of countries of origin that would go a long way towards fulfilling the international obligations of origin countries and towards improving migrant worker protection and accountability within recruitment in the short and medium term. Leaders in countries of origin do have a path forward in the face of multidimensional challenges that are sometimes taken to be insuperable, if those leaders truly wish to look beyond their countries' labour export goals and to prioritize the protection and fulfilment of the human rights of their migrant workers within an equitable sustainable development strategy. 